Chapman University

Chapman University Digital Commons

Food Science (MS) Theses

Dissertations and Theses

Spring 5-2020

\title{
Labeling Compliance, Species Authentication and Net Weight Identification of Frozen Fish Fillets Sold in Grocery Stores in Southern California
}

April Peterson

Chapman University, apeterson@chapman.edu

Follow this and additional works at: https://digitalcommons.chapman.edu/food_science_theses

Part of the Other Food Science Commons

\section{Recommended Citation}

Peterson, A.M. (2020). Labeling compliance, species authentication and net weight identification of frozen fish fillets sold in grocery stores in southern California. Master's thesis, Chapman University. https://doi.org/10.36837/chapman.000141

This Thesis is brought to you for free and open access by the Dissertations and Theses at Chapman University Digital Commons. It has been accepted for inclusion in Food Science (MS) Theses by an authorized administrator of Chapman University Digital Commons. For more information, please contact laughtin@chapman.edu. 
Labeling Compliance, Species Authentication and Net Weight Identification of Frozen Fish Fillets sold in Grocery Stores in Southern California

\author{
A Thesis by \\ April Marie Peterson \\ Chapman University \\ Orange, CA \\ Schmid College of Science and Technology \\ Submitted in partial fulfillment of the requirements for a degree of \\ Master of Science in Food Science
}

May 2020

Committee in charge:

Rosalee Hellberg, Ph.D., Chair

Fredric Caporaso, Ph.D.

Anuradha Prakash, Ph.D. 
The thesis of A:pril Marie Peterson is approved.

Rosalee S. Hellberg

Rosalee S. Hellberg, Ph.D., Chair

Associate Professor, Food Science Program

Schmid College of Science and Technology

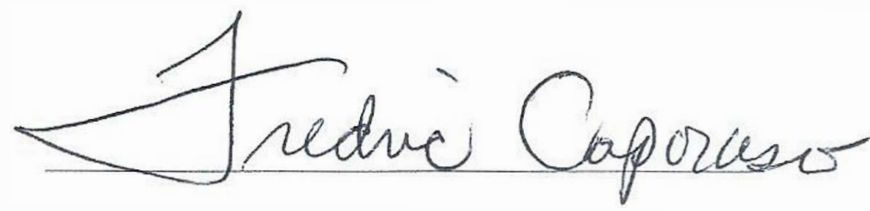

Fredric Caporaso, Ph.D.

Professor, Food Science Program

Schmid College of Science and Technology

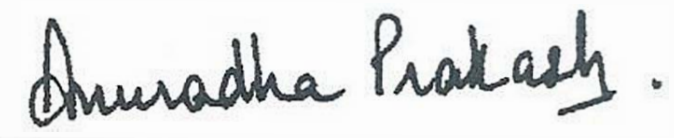

Anuradha Prakash, Ph.D

Director, Professor, Food Science Program

Schmid College of Science and Technology

April 2020 
Labeling Compliance, Species Authentication and Net Weight Identification of Frozen Fish Fillets Sold in Grocery Stores in Southern California

Copyright (C) 2020

by April Marie Peterson 


\section{DEDICATION}

I dedicate my thesis, firstly, to my family. To my loving parents, Rosalia and Douglas Peterson, whose encouraging words pushed me through my time in school. My husband, Miles Shaw, your unwavering support and motivation through my master's thesis, was incredible. 


\section{ACKNOWLEDGMENTS}

I would like to thank my thesis committee members Dr. Hellberg, Dr. Prakash, and Dr.

Caporaso, for guiding me throughout my thesis. I would also like to thank Seeret Jhita and

Gabby McBride for assisting me in the lab, and Carmel Williams of NOAA for training me to deglaze fish fillets properly. 


\begin{abstract}
Labeling Compliance, Species Authentication and Net Weight Identification of Frozen Fish Fillets in Southern California by April Marie Peterson
\end{abstract}

Proper labeling of seafood is important to prevent economic deception, promote consumer awareness, and prevent exposure of at-risk groups to certain allergens and toxins. The objective of this study was to investigate prepackaged frozen fish sold in Southern California for Country of Origin Labeling (COOL) compliance, species authentication, use of acceptable market names, net weights, and percent glaze. A total of 111 frozen fish fillets from 13 different fish categories were purchased from grocery stores in Southern California. The fish categories targeted for this study were: catfish, cod, flounder, halibut, mahi-mahi orange rough, pollock, salmon, swai, swordfish, tilapia, tuna, and whiting. Samples were determined to be COOL compliant if they reported both procurement method and country of origin at the point of sale. Species authentication and acceptable market names were determined by comparing the species identification based on DNA barcoding to the labeling recommendations in the FDA Seafood List. Net weights and percent glaze were determined by recording the weight of each product before and after deglazing. Of the 111 samples, 110 (99\%) were compliant with COOL: the one noncompliant sample displayed the country of origin but did not indicate the production method. Short weighting was detected in 10 of the 111 fish fillets $(9 \%)$ based on the National Institute of Standards and Technology (NIST) standards of maximum allowable weight variation. The average percent glaze was $5 \%$, with a range of $0 \%$ to $34 \%$, and eight samples had $>10 \%$ glaze. The majority of fish (95.5\%) were correctly labeled with regards to species. Species substitution was discovered in two of the $111(1.8 \%)$ samples, and unacceptable market names were observed 
for an additional two samples. Overall, the results of this study indicate a high level of COOL compliance and minimal species substitution in prepackaged frozen fish fillets sold in Southern California. However, the results do suggest a need for increased focus on practices involving short weighting and/or overglazing of frozen fish products. 


\section{TABLE OF CONTENTS}

1. Introduction 1

2. Review of literature $\quad 4$

2.1 Country of origin labeling 4

2.1.1 Country of origin labeling and traceability 6

2.1.2 Country of origin labeling compliance in the U.S. market 7

$\begin{array}{ll}2.2 \text { Species authentication of fish fillets } & 10\end{array}$

2.2.1 Seafood species fraud and mislabeling $\quad 10$

2.2.2 Methods of detecting species substitution $\quad 11$

2.2.3 Seafood mislabeling at retail outlets in Southern California 13

2.3 Glazing of Frozen Fish $\quad 16$

$\begin{array}{ll}2.3 .116 \text { of fish after harvesting } & 16\end{array}$

$\begin{array}{ll}2.3 .218 \text { techniques affect the weight of frozen fish } & 18\end{array}$

2.4 Goal and aims of research $\quad 20$

3. Materials and methods $\quad 21$

3.1 Experimental design $\quad 21$

3.2 Sample collection from grocery stores in Southern California 23

3.3 Country of origin labeling compliance $\quad 23$

3.4 Deglazing and net weight determination $\quad 24$

3.5 DNA barcoding of fish fillets $\quad 25$

3.5.1 DNA extraction and quantification of fish fillets 25

$\begin{array}{ll}\text { 3.5.2 PCR amplification and confirmation } & 26\end{array}$

$\begin{array}{ll}\text { 3.5.3 DNA sequencing } & 27\end{array}$

4. Results and discussion $\quad 28$

4.1 County of origin labeling compliance 28

$\begin{array}{ll}\text { 4.2 Short weighing } & 31\end{array}$

4.2.1 Percent glaze $\quad 34$

4.3 Species authentication and acceptable market names 37

$\begin{array}{ll}\text { 5. Conclusion } & 45\end{array}$

6. References 46 


\section{LIST OF TABLES}

Table 1. Country of origin labeling (COOL) changes in requirements specific to seafood products.

Table 2. Summary of market surveys on fish for compliance with country of origin labeling at U.S. grocery stores.

Table 3. Methods to detect fish species substitution (Naaum \& Hanner, 2016)

Table 4. Summary of market surveys on fish for compliance with species authentication at focusing in Southern California

Table 5. Net weight determination results and \% glaze for the fish samples in this study determined to be overglazed ( $>10 \%$ glaze) and/or short-weighted.

Table 6. Percent glaze based on fish category

Table 7. Combined results of full and mini-DNA barcoding for fish fillets tested in this study $(\mathrm{n}=111)$. Values are displayed as the number count.

Table 8. Samples in this study identified as being mislabeled due to species substitution or use of an unacceptable market name $(n=4)$. 


\section{LIST OF FIGURES}

Figure 1. Similar appearance of white fish fillets from a local grocery store: (a) Pacific cod (Gadus macrocephalus) (b) walleye pollock (Gadus chalcogrammus)

Figure 2. Flow diagram for processing frozen wild fish fillets from fisher to the grocery store.

Figure 3. Experimental design of the study

Figure 4. Example of frozen seafood packaging with COOL, species name, and net weight declared.

Figure 5. DNA extraction from fish fillets.

Figure 6. Percent glaze measured on prepackaged frozen fish fillets $(\mathrm{n}=111)$.

Figure 7. Fillet cuts of frozen flounder (Pleuronectes quadrituberculatus/Pleuronectes platessa) and halibut (Pangasianodon hypothalmus). 


\section{LIST OF ABBREVIATIONS}

AMS- Agricultural Marketing Service

AOAC-Association of Official Agricultural Chemists.

BLAST- Basic Local Alignment Search Tool

BOLD- Barcode of Life Database

COI- Cytochrome C Oxidase Subunit 1

COO- Country of Origin

COOL- Country of Origin Labeling

CR - Control Region

DNA- Deoxyribonucleic acid

E-Gel- Electrolyte energy gel

ELISA- Enzyme-linked immunosorbent assay

FDA - Food and Drug Administration

FFDCA- Federal Food, Drug and Cosmetic Act

IEF- isoelectric focusing

IQF - Individually quick-frozen

IUU- Illegal, unreported and unregulated

MOP-Method of production

NOAA- National Oceanic and Atmospheric Administration

PACA- Perishable Agricultural Commodities Act

PCR- Polymerase Chain Reaction

QC- Quality Control

USDA- U.S. Department of Agriculture 


\section{Introduction}

Americans consumed 2.4 billion $\mathrm{kg}$ of seafood in 2018, making the U.S. the secondlargest global consumer of seafood after China (Lowther et al., 2020). In 2018 alone, 4.3 billion $\mathrm{kg}$ of seafood valued at US $\$ 5.6$ billion was commercially landed in the US. Of the domestic commercial landings, $76.5 \%$ was sold fresh/frozen for human consumption, $1.9 \%$ was canned, $1.5 \%$ was cured, $2.8 \%$ was used for bait and animal food, and $17.3 \%$ was used for production of fish meal, oil, or for other purposes. In addition to commercial fisheries, aquaculture is an important source of seafood in the U.S. and globally. About half of the world's seafood is sourced from aquaculture, with the top three producing countries being China, India, Vietnam. The U.S. Department of Agriculture (USDA) dietary guidelines for Americans recommends consuming $340 \mathrm{~g}$ of seafood each week, equaling $11.8 \mathrm{~kg}$ per year per individual (Lowther et al., 2020). To meet the demands of consumers, the U.S. imports between 85 and $95 \%$ of seafood consumed; however, the U.S. Food and Drug Administration (FDA) only physically inspects about $2 \%$ of imported seafood, which limits their ability to identify instances of mislabeling (GAO, 2009).

Intentional mislabeling of a lower-valued fish species as a higher-valued species is sometimes carried out for economic gain (Hanner et al., 2011). This type of mislabeling can be difficult to detect due to the similar appearance of many fish after the morphological features have been removed during processing. Intentional mislabeling of fish and other food items is prohibited in the U.S. under 21 U.S.C 334: Misbranded food. To avoid the mislabeling of fish, the FDA recommends the use of acceptable market names provided in The Seafood List. However, previous studies conducted in the U.S. have reported the detection of species substitution as well as the use of unacceptable market names for a variety of fish species, 
including fresh and frozen fillets (Bosko et al., 2018; Cline, 2012; Khaksar et al., 2015; Liou et al., 2020; Mitchell et al., 2016; Pollack et al., 2018; Shokralla et al., 2015; Wang et al., 2016; Warner et al., 2013; Willette et al., 2017; Wong et al., 2008). Species mislabeling has not only an economic risk but also a health risk such as exposure to toxins like gempylotoxin and tetrodotoxin found in escolar and pufferfish, respectively (Cohen et al., 2009; Warner et al., 2013). Religious concerns are also brought up with species mislabeling, specifically when nonkosher fish, such as Pangasius spp., are labeled as fish that are considered kosher, such as grouper or sole (Crowell et al., 2018). With regards to fresh/frozen fish fillets, previous U.S. market surveys have reported species mislabeling rates of $18 \%$ for 731 fish from grocery stores across the U.S. (Warner et al., 2013) and 22.5\% for 120 fresh or thawed (previously frozen) fish fillet samples collected from grocery stores in Southern California (Liou et al., 2020; Willette et al., 2017). Liou et al. (2020) reported species substitution in 16 of the 120 samples (13.3\%) and unacceptable market names for an additional 11 samples $(9.2 \%)$.

In addition to species labeling, Country of Origin Labeling (COOL) is required for certain fresh and frozen fish fillets, according to U.S. regulations (Country of Origin labeling for Fish and Shellfish, 7 C.F.R $\S 60)$. COOL is a law requiring retailers under the Perishable Agricultural Commodities Act (PACA) to provide consumers with the geographic origin and production methods of fresh and frozen fish fillets, steaks, and nuggets (USDA, 2020). The information can be displayed on the packaging, placard, band, twist tie, label, or sticker, and it must be legible to consumers. Fish that are imported into the U.S. are also subject to 19 C.F.R § 134.11, which requires country of origin information unless the product is exempt by law. Previous studies investigating COOL compliance among U.S. retailers have found varying results in terms of compliance rates (Bosko et al., 2018; Lagasse et al., 2014; Liou et al., 2020). 
A study conducted in Southern California reported $59 \%$ of 32 catfish products from grocery stores were non-compliant with COOL regulations by failing to report the production method, the country of origin, or both (Bosko et al., 2018). Another study reported that $23.3 \%$ of 120 samples from grocery stores in Southern California were non-compliant with COOL: 15 samples were missing country of origin, nine were missing the production method, and four were missing both (Liou et al., 2020).

Another concern associated with frozen fish is the overuse of glaze and short weighting. A water-based glaze is commonly applied to frozen seafood products to prevent surface drying and dehydration, with adequate levels of glaze reported to be 6-10\% (Vanhaecke et al., 2010). While there are no regulations in the United States regarding the legal amount of glaze that can be used for seafood products, the seafood industry typically applies glaze at levels of 4-10\%, depending on the product (Seafish, 2008). One study conducted over a period of five years in Belgium reported the average glaze on $>700$ samples of frozen fish marketed by a major retailer to be $8.7 \pm 2.0 \%$, with a range of 2.9 to $16.0 \%$ (Vanhaecke et al., 2010). Excess levels of glaze $(>12 \%)$ are sometimes added to increase the net weight of the product artificially. This results in a short-weighted product, with customers unknowingly paying for the extra ice (NOAA, 2014). Seafood products are considered short-weighted if they have a net weight outside of the maximum allowable variation determined by NIST (NIST, 2011). A national survey on short weighting conducted with U.S. seafood industry members reported that half of the respondents $(n=31)$ believed that at least $71 \%$ of net weight violations in the industry were intentional (Santos et al., 2010). Ninety percent of the respondents believed that those who conduct short weighing do not feel that their actions have a negative impact further along the supply chain. Many of the survey respondents indicated frustration with regards to the lack of inspection and enforcement 
for short weighting. Although short weighting is a known problem in the seafood industry, there are no published studies on its prevalence in the marketplace.

While there have been numerous studies on fish species mislabeling, the combination of correct reporting of net weights, COOL compliance, and species authentication have not previously been studied. Therefore, the objective of this study was to investigate prepackaged frozen fish sold in grocery stores in Southern California for COOL compliance, species authentication, use of acceptable market names, net weights, and percent glaze.

\section{Review of literature}

\subsection{Country of origin labeling}

Labeling the country of origin in food products is not a new concept. Since the United States Tariff Act of 1930, imported processed food required the country of origin information to be marked on the package (Flegenheimer, 2017). While the Tariff Act covers processed seafood products, the Farm Security and Rural Investment Act of 2002 (Farm Bill) covers fresh and frozen seafood (USDA, 2020). The 2002 Farm Bill introduced mandatory COOL for beef, pork, chicken, goat meat, wild and farm-raised fish and shellfish, perishable commodities, and nuts, which became effective in 2005 (GAO, 2009; USDA, 2002). With regards to seafood, COOL requires retailers to notify consumers of the country of origin and procurement method (wild or farmed) for each product sold by retailers under the Perishable Agricultural Commodities Act (PACA) (USDA, 2020). Retailers are required to get a PACA license when they purchase US $\$ 230,000$ or more fresh or frozen produce in a calendar year. Retailers include most grocery stores and supermarkets; excluded from the COOL regulations are fish markets, butcher shops, restaurants, and small stores that do not sell the threshold amount of fresh produce. COOL 
regulations cover unprocessed commodities, including farm-raised and wild fish and shellfish (fillets, streaks, nuggets, and any other flesh). The information must be displayed in a conspicuous location where they are likely to be read and understood by a customer (USDA, 2020). The rule also provides options for presenting the country of origin declarations, by being placed on a placard, sign, label, sticker, band, twist tie, pin tag or other formats so the customer can identify the country of origin of the product. An amendment to the Farm Bill published in 2008 included additional wording options for identifying the production methods of fish and how the county of origin is written out on packages, as well as adjustments to record-keeping requirements and penalties (Table 1).

Table 1. Country of origin labeling (COOL) requirements specific to seafood products.

\begin{tabular}{|c|c|c|}
\hline $\begin{array}{l}\text { COOL } \\
\text { Requirement }\end{array}$ & $\begin{array}{l}\text { Farm Bill } 2002 \text { \& Final rule } \\
2004\end{array}$ & Farm Bill 2008 \& Final Rule 2009 \\
\hline Labeling & $\begin{array}{l}\text { - } \text { Retailer at point of sale } \\
\text { - } \\
\text { Production method (farmed or } \\
\text { wild) \& country of origin }\end{array}$ & $\begin{array}{l}\text { Various forms of production methods } \\
\text { acceptable: wild, wild-caught, farm- } \\
\text { raised, farmed, or a combination. } \\
\text { - Abbreviations of country acceptable }\end{array}$ \\
\hline $\begin{array}{l}\text { Country of } \\
\text { origin }\end{array}$ & $\begin{array}{l}\text { - Single country of origin } \\
\text { (exclusively): U.S. origin } \\
\text { - Multiple country origin: } \\
\text { Product from (country X), } \\
\text { processed in (country Y) }\end{array}$ & $\begin{array}{l}\text { - Multiple country origin: Product from } \\
\text { (country X), processed in (country Y). } \\
\text { or Product of country X and country } \\
\text { Y }\end{array}$ \\
\hline Recordkeeping & $\begin{array}{l}\text { - Everyone in the supply chain } \\
\text { - Certain parties maintain } \\
\text { records as required }\end{array}$ & $\begin{array}{l}\text { - Any record maintained from the } \\
\text { conduct of business } \\
\text { - Authorities cannot require additional } \\
\text { records }\end{array}$ \\
\hline Exceptions & $\begin{array}{l}\text { - } \text { Processed product } \\
\text { - } \text { Foodservice } \\
\text { - } \text { Specialties markets }\end{array}$ & $\begin{array}{l}\text { - Consumer ready food imports now } \\
\text { need COOL }\end{array}$ \\
\hline Enforcement & $\begin{array}{l}\text { - } \text { Retailer - maximum US } \\
\$ 10,000 \text { fine per willful } \\
\text { violation } \\
\text { - Supplier - cease and desist } \\
\text { order and civil penalty } \\
\text { (USDA, 2002) }\end{array}$ & $\begin{array}{l}\text { - } \text { Retailer/supplier- civil penalty } \\
\text { - }\end{array}$ \\
\hline
\end{tabular}




\subsubsection{Country of origin labeling and traceability}

Country of origin labeling is an essential component of traceability. Traceability refers to the ability to ensure the tracking of activities, information, and elements of a product as it moves along the supply chain from raw goods to finished goods to the consumer (Rouse et al., 2016). It is imperative to be able to track a product through the entire supply chain to make it easier for inspectors to investigate and troubleshoot issues related to a component or ingredient, which is crucial in times of recalls. Hence, stakeholders have the means to locate the source of the problem. Government-mandated seafood traceability rules are in place to disclose countries of origin as a fraud prevention measure. Traceability and country of origin labeling can also help combat the trade of illegal, unreported, and unregulated (IUU) fish and seafood. The long term effects of IUU fishing include a reduction in fish stocks, increased fishing costs, and higher prices to consumers (Tinch et al., 2008; Zimmerhackel et al., 2018). Annual global losses of IUU fishing have been estimated between US $\$ 9$ to $\$ 23$ billion; specifically, IUU catches accounted for 20-23\% by weight of wild-caught seafood imported to the U.S. in 2011 (Ewell et al., 2017; Pramod et al., 2014). The U.S. Seafood Import Monitoring Program, published by NOAA Fisheries, was created as part of an action plan combating IUU fishing and seafood fraud. The Seafood Import Monitoring program is a risk-based traceability program requiring records to be reported at the point of import, harvest, and entry into U.S. commerce (NOC, 2014).

The Global Food Traceability Center surveyed nine global seafood value chains that integrated traceability into their businesses (Sterling et al., 2015). Each one saw more commercial benefits with integrated traceability than before implementation. An integrated approach to traceability in seafood supply chains would also be expected to contribute to fraud prevention. Enhanced traceability connects data of the supply chain of each product, where it 
went, what processes it underwent, who handled it, etc. Knowing this type of information can be useful to detect irregular trends occurring within the supply chain at different points, which can help identify issues arising and fraudulent activity.

\subsubsection{Country of origin labeling compliance in the U.S. market}

A small number of market studies have been conducted on country of origin labeling (COOL) compliance in the U.S. market with varying results (Table 2). A market survey conducted in Baltimore, Maryland (MD), focused on COOL compliance of fish and shellfish sold in grocery stores (Lagasse et al., 2014). The goal was to identify COOL information available to consumers before and at the point of purchase, as well as the difference between instore advertisements and seafood labels. Lagasse et al. (2014) photographed samples from 14 stores in the Baltimore area during bi-monthly visits conducted over three months between November 2010 and January 2011; each store was visited four times. Non-packaged fresh, packaged fresh, and frozen seafood samples were photographed in each store to evaluate the COOL information provided to the customers, photographing a number of the same fish repeatedly resulting in 628 data points altogether. Lagasse recorded the species, seafood cut type, and price for all samples. Circulars were also collected to observe COOL in advertisement and compare it with in-store labeling. 
Table 2. Summary of market surveys on fish for compliance with country of origin labeling at U.S. grocery stores.

\begin{tabular}{lllll}
\hline Location & Sample type & $\begin{array}{l}\text { No. of } \\
\text { samples }\end{array}$ & Results & Reference \\
\hline $\begin{array}{l}\text { Baltimore } \\
\begin{array}{l}\text { City, } \\
\text { Maryland }\end{array}\end{array}$ & $\begin{array}{l}\text { Fresh/frozen fish from 14 grocery } \\
\text { stores, with 28 repeat visits. }\end{array}$ & $\begin{array}{l}628 \\
\text { packages }\end{array}$ & $\begin{array}{l}3.8 \% \\
\text { noncompliant }\end{array}$ & $\begin{array}{l}\text { (Lagasse, } \\
2014)\end{array}$ \\
$\begin{array}{l}\text { Southern } \\
\text { California }\end{array}$ & $\begin{array}{l}\text { Variety of catfish from 39 } \\
\text { grocery stores }\end{array}$ & 32 catfish & $\begin{array}{l}59.3 \% \\
\text { noncompliant }\end{array}$ & $\begin{array}{l}\text { (Bosko et al., } \\
\text { 2018) }\end{array}$ \\
& $\begin{array}{l}\text { Fresh/thawed fish from 30 } \\
\text { grocery stores. }\end{array}$ & 120 fish & $\begin{array}{l}24 \% \\
\text { noncompliant }\end{array}$ & $\begin{array}{l}\text { (Liou et al., } \\
\text { 2020) }\end{array}$ \\
\hline
\end{tabular}

Lagasse et al. (2014) reported $96.2 \%$ of the samples were COOL compliant. Of all samples, $1.9 \%$ did not state the country of origin, $2.7 \%$ did not state the production method, and $1.1 \%$ listed neither country of origin nor procurement method. There were 37 different fish species sold in the stores; the most common were salmon (13.9\%), tilapia (13.5\%), catfish (10.1\%), and shrimp (9.7\%). The authors reported that the origin and procurement information was sometimes difficult to locate because they were printed in small font on the back of the package. The procurement information was highlighted more frequently compared to the origin in all advertisements.

Lagasse et al. (2014) concluded that the advertisements played an essential role in consumer purchasing. The marketing and labeling practices found in the grocery stores can shape demand, desires, and expectations of the market by emphasizing one procurement method over the other, or the origin of the fish. Lagasse et al. (2014) also indicated the need for future research in how the information presented influences the decision making at the point of purchase for consumers. While this market survey only examined 30 grocery stores in Baltimore, an Agricultural Marketing Service (AMS) conducted a market survey in 2016, examining over 3,000 retail stores across the United States. The AMS study observed a total of 79,928 fish and 
shellfish products for COOL compliance. Of these 79,928 products, $10 \%$ were noncompliant with COOL (Liou et al., 2020).

Another market survey that investigated COOL compliance focused on catfish sold in Southern California (Bosko et al., 2018). Bosko et al. (2018) gathered 40 catfish samples from 39 local grocery stores and fish markets and 40 samples from 40 local restaurants for a total of 80 catfish samples. The catfish purchased from grocery stores were collected from both the fresh and frozen sections and examined for COOL compliance. Of the 32 samples from grocery stores, 19 were missing the country of origin information, procurement method, or both, indicating noncompliance with COOL. Although fish markets and restaurants are not subject to COOL regulations, country of origin labeling was examined for these samples as well. Six out of eight samples from fish markets did not list the country of origin or procurement method. Although the results of this study indicated a seemingly high rate of COOL noncompliance (59\%) in grocery store samples, additional research is needed on COOL compliance among catfish products in the U.S. market.

A subsequent market survey conducted in the Southern California region focused on a wide variety of fresh or thawed (previously frozen) fish purchased solely at grocery stores (Liou et al., 2020). The researchers collected fish fillets $(n=120)$ from 30 grocery stores in Orange County, California. The targeted fish were salmon, cod, tuna, halibut, tilapia, catfish, pangasius, rockfish, snapper, sole, trout, swordfish, mahi-mahi, bass, and yellowtail. A maximum of 10 fish per category was collected, with no more than two samples from the same category purchased at the same store. COOL information and species labeling were noted at the time of purchase. Of the 120 samples, 28 were noncompliant with COOL: 15 samples did not state country of origin, 9 did not have the production method, and 4 samples were missing both the country of origin and 
production method. Of the noncompliant samples, some were missing the information altogether, while others listed multiple or contradictory country names, and others had unacceptable country names. Only four of the 15 fish categories (i.e., rockfish, rockfish/snapper, trout, and cod) had samples that were all compliant with COOL. The remaining categories each had at least one sample that was noncompliant with COOL.

\subsection{Species authentication of fish fillets}

\subsubsection{Seafood species fraud and mislabeling}

It is illegal under the Federal Food, Drug, and Cosmetic Act (FFDCA) to intentionally mislabel food (FDA, 2017). However, fraudsters can make a profit by selling low-valued fish that has been substituted for high-valued fish. Seafood is highly vulnerable to be substituted on the basis of species because many species are similar in appearance, and it is difficult to identify fish based only on appearance. For example, fillets of white fish such as cod and pollock are visually very similar (Figure 1). As fish is processed, the morphological characteristics are lost, and it becomes more challenging to identify species. Some examples of commonly substituted fish include cod substituted for Alaska pollock, steelhead trout for salmon, farm-raised salmon for wild-caught salmon, mahi-mahi for yellowtail, and swordfish for mako shark (FDA, 2018).

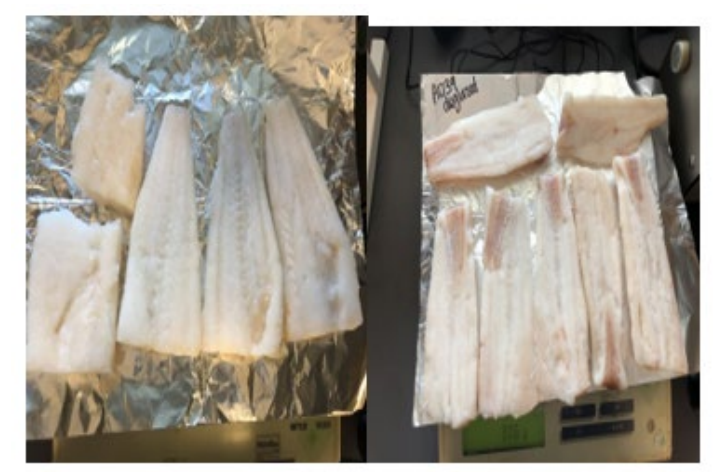

Figure 1. Similar appearance of white fish fillets from a local grocery store: (a) Pacific cod (Gadus macrocephalus) (b) walleye pollock (Gadus chalcogrammus). 
Not only does mislabeling cause an economic loss for consumers, but it can also introduce health hazards. For example, escolar, which is commonly substituted for white tuna and seabass, can cause gastrointestinal discomfort, diarrhea, and cramps because of the gempylotoxin it contains (Yohannes et al., 2002). Another example of a safety hazard associated with species substitution is in the case of the pufferfish that was mislabeled as monkfish; pufferfish causes paralysis and even death from tetrodotoxin poisoning leaving monkfish consumers at risk (Cohen et al., 2009). In 2007, two cases of tetrodotoxin poisoning occurred after pufferfish mislabeled as monkfish was consumed in a home-cooked soup. The mislabeled pufferfish was purchased from a Chicago marketplace; however, both the market place and the supplier denied having knowingly sold or imported pufferfish.

Another challenge with mislabeling is the use of acceptable market names. The FDA recommends that the seafood industry use either the common name or the acceptable market name on the product label. A list of common names and other acceptable market names is provided for over 1800 fish species in the FDA's Seafood List (FDA, 2012). However, acceptable market names are not always used by the industry.

\subsubsection{Methods of detecting species substitution}

Seafood species can be identified using a variety of methods, including morphology, protein-based, and DNA-based methods. The morphology of species refers to the physical features of the animal, i.e., its shape, color, and size. However, morphology is usually carried out by experts, thus making it an impractical method for consumers to with which to evaluate fish species [Error! Reference source not found.; (Naaum et al., 2016)]. Furthermore, some processed fish is skinned and breaded, such as fillets, which makes it challenging to identify because of the removal of identifiable features. Protein-based methods such as enzyme-linked immunosorbent 
assay (ELISA) and isoelectric focusing (IEF) are reliable for testing fresh, lightly processed fish samples (Error! Reference source not found.). However, these methods are less sensitive than DNA-based methods, making it challenging to identify species in processed products (Dunbar et al., 2003).

Table 3. Methods to detect fish species substitution (Naaum \& Hanner, 2016).

\begin{tabular}{|c|c|c|c|}
\hline Method & Used for & Pros & Cons \\
\hline Morphology & Whole fish & $\begin{array}{l}\text { Experts can identify } \\
\text { without the need for testing }\end{array}$ & $\begin{array}{l}\text { Nonexperts may have } \\
\text { difficulties }\end{array}$ \\
\hline ELISA & $\begin{array}{l}\text { Lightly } \\
\text { processed fish }\end{array}$ & Rapid testing & $\begin{array}{l}\text { Less sensitive } \\
\text { than DNA } \\
\text { Costly }\end{array}$ \\
\hline IEF & $\begin{array}{l}\text { Lightly } \\
\text { processed fish }\end{array}$ & $\begin{array}{l}\text { Control the formation of a } \\
\text { gradient without further } \\
\text { staining }\end{array}$ & $\begin{array}{l}\text { Less sensitive than } \\
\text { DNA } \\
\text { costly }\end{array}$ \\
\hline Species-Specific PCR & $\begin{array}{l}\text { All fish types, } \\
\text { including highly } \\
\text { processed }\end{array}$ & $\begin{array}{l}\text { Easy to use } \\
\text { Sensitive }\end{array}$ & $\begin{array}{l}\text { Does not test for a } \\
\text { broad range of } \\
\text { species }\end{array}$ \\
\hline $\begin{array}{l}\text { DNA } \\
\text { sequencing/DNA } \\
\text { barcoding }\end{array}$ & All fish types & $\begin{array}{l}\text { Simultaneously tests for a } \\
\text { range of species } \\
\text { Sensitive }\end{array}$ & $\begin{array}{l}\text { Relatively labor and } \\
\text { time-intensive } \\
\text { Can be costly }\end{array}$ \\
\hline
\end{tabular}

DNA-based methods are widely implemented because of their accuracy, sensitivity, and versatility (Naaum \& Hanner, 2016). The type of DNA-based method selected is dependent on cost, sample type, equipment, and other factors (Table 3). Species-specific PCR is a targeted method used to identify a select fish species or group of species. It also typically works well with processed samples, as long as the PCR amplicon is relatively short ( $<250 \mathrm{bp})$. For example, in the market survey conducted by Bosko et al. (2018), real-time species-specific PCR was used to identify catfish species in a range of samples, including those that were fried, steamed, and grilled. However, species-specific PCR does not simultaneously test for a broad range of species. On the other hand, DNA barcoding is a universal method that allows for the identification of a wide variety of fish species. DNA barcoding is a DNA sequencing-based method, which reveals the actual nucleotide sequence of DNA (Naaum \& Hanner, 2016). DNA barcoding uses short 
standardized genetic markers to identify species (Hebert et al., 2003). The primary genetic marker for animals for DNA barcoding is a $\sim 655 \mathrm{bp}$ region of the gene coding for cytochrome $\mathrm{c}$ oxidase subunit I (COI), located within the mitochondrial DNA. The COI mitochondrial gene shows sufficient variation to differentiate species while the PCR primers used bind conserved regions. The DNA barcode sequence for an unknown sample can be compared against reference sequences in the Barcode of Life Database (BOLD) to identify the species. BOLD contains over seven million COI DNA barcodes equivalent to 200,000 species (BOLD, 2020). Short regions of the DNA barcode ( $<250 \mathrm{bp})$ called mini-barcodes are sometimes used to identify species in processed products.

\subsubsection{Seafood mislabeling at retail outlets in Southern California}

Several studies have revealed the mislabeling of seafood species sold at retail outlets in Southern California. From 2010 to 2013, Oceana conducted market surveys across the U.S. to observe species mislabeling in the markets (Warner et al., 2013). In Southern California, they collected 121 samples (32 samples from Orange County and 89 from Los Angeles) and found that $52 \%$ of them were considered mislabeled. Of the fish species collected, snapper was the most commonly collected and most often mislabeled. All of the 34 snapper samples were considered mislabeled according to the FDA guidelines, and only was one correctly labeled according to the California law that allows 13 species of rockfish to be sold ad "Pacific red snapper." Of the 74 retail outlets visited, 45 sold mislabeled seafood. Grocery stores had lower amounts of mislabeling (32\%) compared to restaurants and sushi venues. Of the 21 sushi venues visited, only one sold correctly labeled fish, and the other 20 sold at least one fish that was mislabeled according to FDA guidelines ( $84 \%$ of the sushi samples were mislabeled). 
Willette et al. (2017) conducted a study in Los Angeles observing the species authentication of sushi obtained from restaurants and grocery stores over a four year period (Table 4). A total of 364 fish samples were collected from 26 sushi restaurants in Los Angeles, CA. Nine fish species were targeted: albacore tuna (Thunnus alalunga), yellowfin tuna (T. albacares), bigeye tuna (T. obesus), bluefin tuna (T. thynnus, T. maccoyii, T. orientalis), red snapper, yellowtail (Seriola lalandi), halibut (Hippoglossus hippoglossus, H. stenolepis), mackerel (Scomber spp., Scomberomorus spp.), and salmon (Salmo salar, Oncorhynchus spp.) (Willette et al., 2017). The study considered the samples to be mislabeled if they were inconsistent with FDA acceptable market names. The authors found a high percentage of mislabeling among the sushi samples tested $(47 \% ; 151 / 323)$ from 2013 to 2105 . However, the mislabeling was not homogenous across the species; halibut, red snapper, and yellowtail had consistently high $(>77 \%)$ occurrences of mislabeling on the menus, and salmon and mackerel were low $(<15 \%)$. All sampled sushi restaurants (26) had at least one case of mislabeling (45.5\%), which was a higher rate compared to that of sushi collected from grocery stores $(3 ; 42 \%)$. The discrepancies in the names could be attributed to confusion associated with labeling laws or retailers falling victim to fraudsters. Willette et al. (2017) recommended educating the consumers of seafood species mislabeling to develop/support federal policies that would strengthen seafood traceability by using COOL and scientific names. 
Table 4. Summary of market surveys on fish species authentication conducted in Southern California

\begin{tabular}{|c|c|c|c|c|}
\hline Location & Sample type & No. of samples & Results & Reference \\
\hline \multirow[t]{2}{*}{$\begin{array}{l}\text { Southern } \\
\text { California }\end{array}$} & $\begin{array}{l}40 \text { from restaurants } \\
40 \text { from retail outlets }\end{array}$ & 80 catfish & $\begin{array}{l}\sim 90 \% \text { positive for } \\
\text { catfish } \\
8.75 \% \text { species } \\
\text { mislabeled }\end{array}$ & $\begin{array}{l}\text { (Bosko et } \\
\text { al., 2018) }\end{array}$ \\
\hline & $\begin{array}{l}\text { Variety of fresh or } \\
\text { thawed fish from } \\
30 \text { grocery stores }\end{array}$ & $\begin{array}{l}120 \text { fish } \\
\text { samples }\end{array}$ & $\begin{array}{l}13 \% \text { substituted on the } \\
\text { basis of species } \\
10 \% \text { mislabeled } \\
\text { market name }\end{array}$ & $\begin{array}{l}\text { (Liou et } \\
\text { al., 2020) }\end{array}$ \\
\hline $\begin{array}{l}\text { Los } \\
\text { Angeles, } \\
\text { California }\end{array}$ & $\begin{array}{l}\text { From } 26 \text { sushi } \\
\text { restaurants for over } 4 \\
\text { year }\end{array}$ & $\begin{array}{l}364 \text { fish } \\
\text { samples }\end{array}$ & $\begin{array}{l}47 \% \\
(151 / 323) \\
\text { In 2012 - } 2015\end{array}$ & $\begin{array}{l}\text { (Willette } \\
\text { et al., } \\
\text { 2017) }\end{array}$ \\
\hline $\begin{array}{l}\text { Southern } \\
\text { California }\end{array}$ & $\begin{array}{l}47 \text { from grocery stores } \\
31 \text { from restaurants } \\
43 \text { sushi }\end{array}$ & 121 samples & $52 \%(63 / 121)$ & $\begin{array}{l}\text { (Warner et } \\
\text { al., 2013) }\end{array}$ \\
\hline
\end{tabular}

Bosko et al. (2018) collected 80 catfish from restaurants and local retailers, as described in

section 2.1.2. Real-time PCR was performed on the fish samples to identify the species. For samples that could not be identified with real-time PCR, DNA barcoding was used. The results showed that out of 80 samples, 73 were verified to be catfish (Ictaluridae), and seven were Pangasiidae, which is considered to be improper labeling of catfish in the U.S (Table 4). The rate of mislabeling was higher at restaurants $(12.5 \%)$, which contained mostly breaded fish compared to fresh/frozen fish at grocery stores (5\%) (Table 4).

Another study conducted in Southern California examined fresh or thawed (previously frozen) fish fillets purchased at 30 grocery stores (Liou et al. (2020). The authors sampled a total of 120 fish from 16 different categories including bass, catfish, cod, halibut, mahi-mahi, pangasius, rockfish, rockfish/snapper, snapper, salmon, sole, swordfish, tilapia, trout, tuna and yellowtail. All of the 120 samples collected were successfully sequenced with DNA barcoding or mini-barcoding (Liou et al., 2020). Four samples failed full barcoding but were successfully sequenced with a COI mini-barcode primer set. These samples were identified as Patagonian 
toothfish (Dissostichus eleginoides), Atlantic salmon (Salmo salar), and Antarctic toothfish (Dissostichus mawsoni) (Liou et al., 2020). A total of 81 fillets were identified to the species level, 24 were identified to the genus level, and 15 samples showed top matches to multiple species in different genera. Sixteen of the 120 samples were substituted on the basis of species, with snapper fillets having the highest rate of substitution (3/3). Yellowtail fillets also had a relatively high rate of substitution (2/4), followed by cod (3/10) and bass $(2 / 7)$. Among the 120 samples analyzed by Liou et al. (2020), 12 fillets from 10 stores had unacceptable market names (Table 4). There was an overall mislabeling rate of $23.3 \%$ when data for species substitution and unacceptable market names were combined. Samples were noncompliant if the country of origin was missing, stated as "other," listing multiple countries, or did not use a valid country name. When COOL compliance was also considered, 49 out of 120 samples had at least one error in labeling. There were several instances of high-valued species being substituted with lower-valued ones, such as Chilean seabass being substituted with swordfish for possible economic gain. Some $(\mathrm{n}=2)$ of the mislabeling in this study was a result of name confusion when associated with sushi (i.e., used the term "Madai" for red snapper) (Liou et al., 2020).

\subsection{Glazing of frozen fish}

\subsubsection{Preservation of fish after harvesting}

Fish are harvested from either a farm or captured from the wild by a variety of tools such as nets, traps, hooks, and lines. Most fish are placed onto fish vessels for temporary storage after harvesting, where they are transported to shore processing facilities (Moody, 2003). Figure 2 describes the steps that the fish undergo after being procured by fishing vessels. The collected fish are iced, chilled, or frozen on board depending on time and distance to shore. Some fishing 
vessels are large enough to have processing facilities onboard, where they usually perform block freezing. Block freezing fish is when fish are gathered in a container, water is poured over, and the fish are frozen in the block shape (Kerry, 2012). Block frozen fish are easier to store in the freezer compared to individually quick frozen (IQF) fish because the blocks can stack on top of one another, utilizing limited storage space. Onboard and offshore processing are each carried out using similar procedures [Figure 2; (Silva, 2001)]. IQF fish receive a water glaze after freezing. The filleted frozen fish leave the freezer and are conveyed through a water bath where the glaze is formed over the fish. The fillets are then sized, packaged, and sent to wholesalers, secondary processors, and/or retail outlets. Other options onboard a fishing vessel include packaging the fish into 15 -lb boxes without glazing. Processing is also done offshore for smaller vessels where the same process is fulfilled. There is no current regulation on the proper way of storing frozen fish; fishers and producers pick which one best suits their needs.

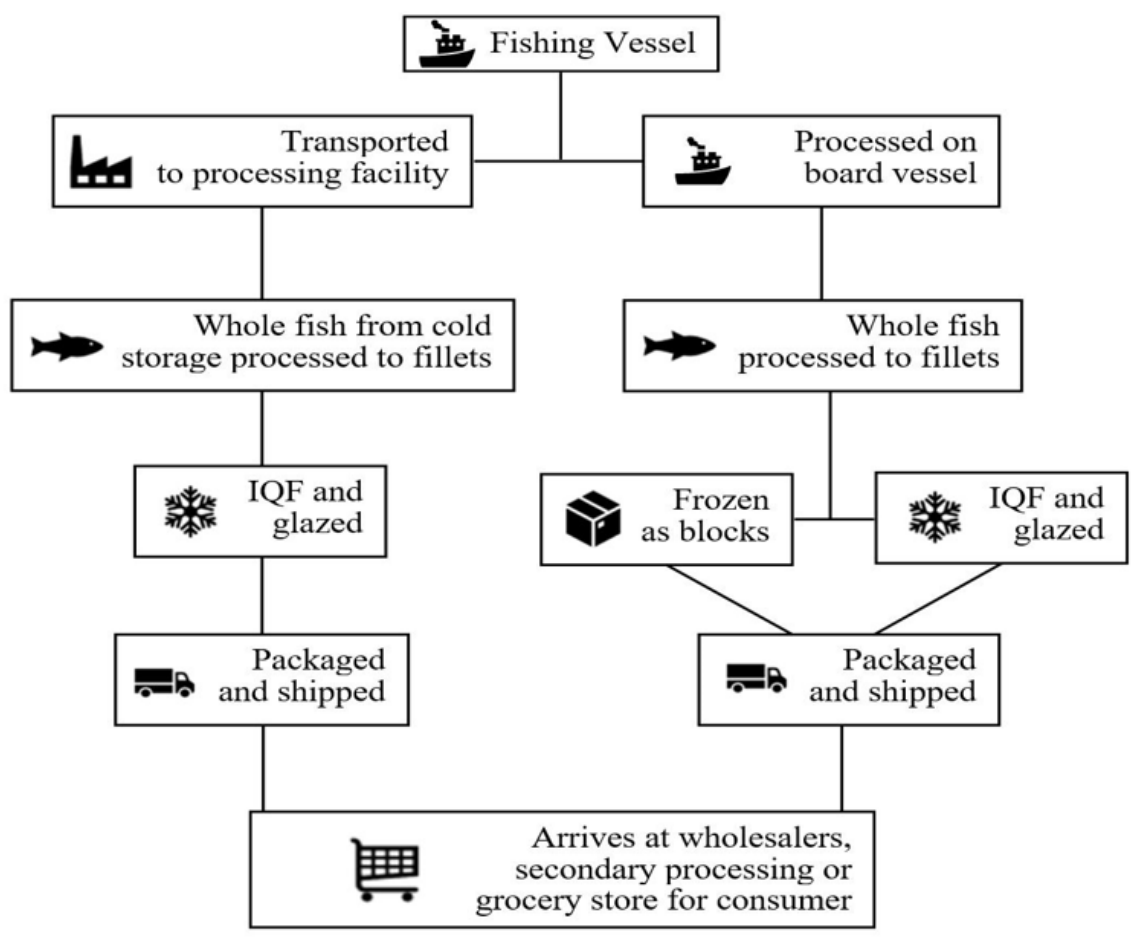

Figure 2. Flow diagram for processing frozen wild fish fillets from fisher to the grocery store. 
There are two different ways that glaze is added to IQF fish products; these include the dipping method and the spraying method. The dipping method involves frozen seafood products that are immersed in a tank filled with cold water for a period of time and then flash-frozen to create an ice coat surrounding the fish (Soares, 2016; Soares et al., 2015). The spraying method uses equipment to spray the glaze on the seafood. Although the dipping method is cheaper and simpler than the spraying method, it is more difficult to control the uniformity and amount of glaze for the fish. The amount of glaze added is dependent on a) the product and glazing temperatures, b) the size and surface area of the product, and c) the glazing time (Soares, 2016; Soares et al., 2015).

\subsubsection{Preservation techniques affect the weight of frozen fish.}

Glazing of fish is done to prevent freezer burn during storage and transport. Overglazing occurs when the glaze amount no longer is added to extend shelf life but to add weight to the product. Overglazing could serve as a potential outlet of fraud by artificially adding weight to the product, resulting in an economic profit. A study conducted in Belgium examined 712 pieces of frozen fish marketed by a major retailer and found that $86.1 \%$ of the samples had $6-12 \%$ glaze (Vanhaecke et al., 2010). Excess glaze (>12\%) was found with 5.6\% of the samples. When considering the fish on a batch basis (i.e., per bag), the range of glaze was $6.6 \pm 2.2 \%$ (salmon/cod) to $10.6 \pm 1.6 \%$ (plaice). The authors found that the glazing amount could be affected by the time of year: in the summer months, fish had an average glaze of $8.16 \%$, the average for fall and spring combined was $8.61 \%$ and winter months had an average of $9.55 \%$ glaze. Vanhaecke et al. (2010) believed that the differences in product temperature thought the year could explain the variability in the glazing percentages. 
One study examined the effect of three frozen storage methods on the wet weight of fish. The wet weight of the fish is a common biological descriptor that is used to calculate the body condition, percent dry weight, and the gonadosomatic index (Crane et al., 2016). Many factors can affect wet weight, such as the preservation methods used during freezing. The most commonly used frozen storage techniques on frozen fish are vacuum-sealed and water glaze, both of which affect the wet weight and percent dry weight estimates of fish. Crane et al. (2016) investigated Emerald shiners and Rudd species collected from the Niagara River. The fish were euthanized, weighed, randomly assigned to one of the three preservation methods, and frozen immediately. The frozen fish were stored for three to seven months, depending on drying oven capacity. Each sample was stored in a container to allow efficient freezing, then placed in plastic freezer bags with the removal of excess air. The specimens were thawed under cold running water and placed in the sealed bag. Once thawed fully, the fish were patted down with a paper towel, and the final wet weights were measured. Each sample was dried at $60^{\circ} \mathrm{C}$, and the final dry weight was recorded (Crane et al., 2016).

The results of Crane et al. (2016) study indicate that the post-thawed wet weights were different from the pre-stored wet weights in all three storage methods for the two fish types. Specific trends emerged: the samples frozen in water increased in wet weight after storage, whereas the vacuum-sealed and glazed fish had decreased wet weights. The second trend was that smaller fish were more affected by the freezing than the larger fish. Thirdly, the effect of the storage method had the most significant effect on the wet weight in comparison to the size and duration of storage. Glazed and vacuum-sealed storage methods had more effect on wet-weight than freezing in the water. The difference between the storage methods' effects on the fish tissue could explain the weight difference. The fish frozen in water would have absorbed water until 
they were completely frozen, thus increasing the weight of the fish. Whereas in the vacuumsealing processed fish, there was body fluid leakage due to the compression of the tissue during treatment (Crane et al., 2016). The wet weight is a crucial factor when it comes to freezing fish; this weight can be manipulated to make the fish seem more substantial than it is.

A national survey conducted in the U.S. on the practices of short weighting was published in 2010 to assess the seafood industry's standing on short weighting (Santos et al., 2010). Of the individuals who took the survey, half of the respondents $(n=31)$ believed that at least $71 \%$ of the net weight violations in the industry were intentional. The comments on the survey suggested that buyers have full knowledge of the fact that they are purchasing shortweighted products. Ninety percent of the survey responders believed that the individuals who are short weighting do not feel their actions have an impact on the supply chain. When asked of the percentage of firms that violate the regulations for net weight, over half of the respondents $(58 \%$ of 62 individuals) indicated that about a third of all firms violate regulations. However, $63 \%$ indicated that they would do nothing if they learned about another company was practicing short weighing. The majority of the survey respondents believed that short weighting is an issue in both imported and domestic products. The lack of international standards of measurements may be a cause of short weighting for seafood. The response from the seafood industry indicated frustration at short weighting and the lack of attention it receives by regulatory agencies (Santos et al., 2010).

2.4 Goal and aims of the research

The objective of this study was to investigate prepackaged frozen fish sold in Southern California for Country of Origin Labeling (COOL) compliance, species authentication, use of acceptable market names, net weights, and percent glaze. The specific aims were to: (1) Observe 
COOL compliance within the store and on the packaging of the fish; (2) Determine the net weight and percent glaze for each fish sample purchased to determine whether samples were short-weighted and/or overglazed; (3) To authenticate the species of the fish acquired using DNA barcoding; and (4) To determine whether acceptable market names were used on the packaging.

The central hypothesis, based on previous studies conducted in the Southern California region is that less than $40 \%$ of frozen fish samples will be non-COOL compliant, less than $10 \%$ will have mislabeled species, and less than $5 \%$ will be overglazed resulting in short weighting (Bosko et al., 2018; Lagasse et al., 2014; Liou et al., 2020).

The information evaluated is crucial in identifying if there is a need to be more rigorous when inspecting the fish on the market. This contribution is significant since there has not been a study evaluating all three of these labeling aspects within frozen fish before this research.

\section{Materials and methods}

3.1 Experimental design

Steps to identify fish species, COOL compliance, glaze amount, and net weight are outlined in Figure 3. 


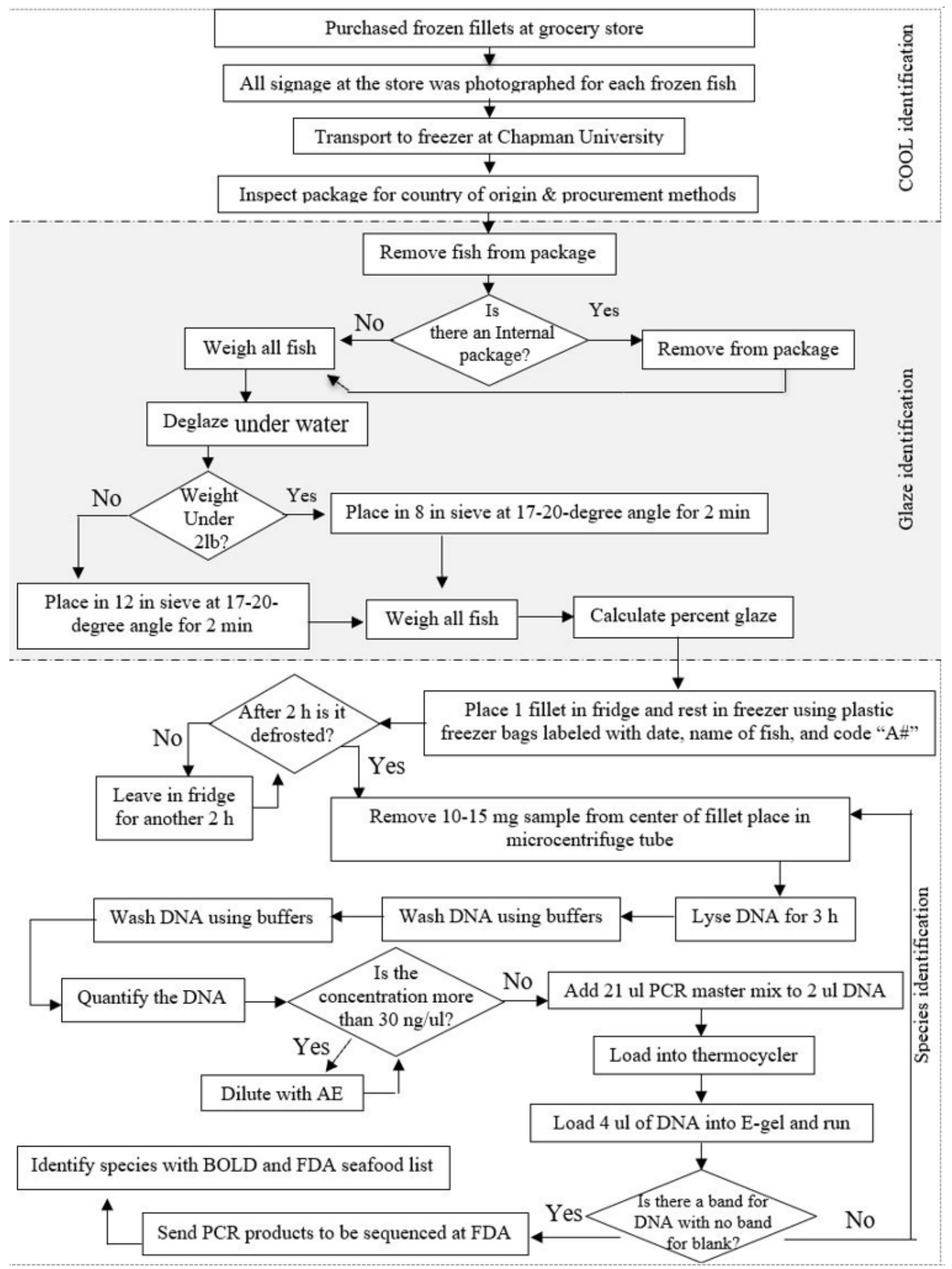

Figure 3. Experimental design of the study 


\subsection{Fish sample collection from grocery stores in Southern California}

A total of 111 frozen fish fillets were collected from 38 grocery stores in Southern California. The stores were located within approximately 40 miles of Chapman University and were in 15 different cities in Orange County, Los Angeles County, and Riverside County. All grocery stores visited for sample collection were licensed under PACA, according to USDA's PACA search engine (http://apps.ams.usda.gov/pacasearch/). Only unique products were collected (i.e., no repeat sampling of the exact same product). The selection of fish was based on availability at stores and included the following 13 categories: catfish $(n=4), \operatorname{cod}(n=15)$, flounder $(n=7)$, halibut $(n=7)$, mahi-mahi $(n=10)$, orange roughy $(n=2)$, pollock $(n=7)$, salmon $(\mathrm{n}=15)$, swai $(\mathrm{n}=8)$, swordfish $(\mathrm{n}=2)$, tilapia $(\mathrm{n}=15)$, tuna $(\mathrm{n}=15)$, and whiting $(\mathrm{n}=$ 4). A maximum of 15 fish samples was purchased per category.

\subsection{Country of origin labeling compliance}

COOL compliance was evaluated by observing the labeling associated with each product, including tags, placards, signs, and/or packages. Photos were taken of each frozen fish fillet in the store and with the packaging removed, the front and back of the packaging, the location of COOL information, and the receipts. After purchase, the fish samples were transported to the laboratory in a cooler with ice packs and stored at $-20^{\circ} \mathrm{C}$ until deglazing and net weight determination (Figure 4). 


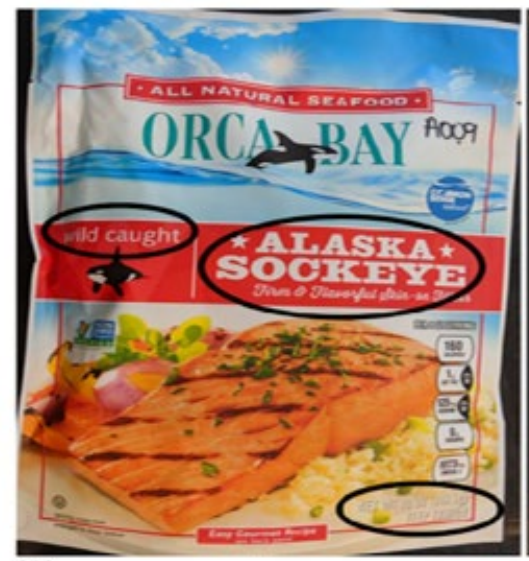

(A)

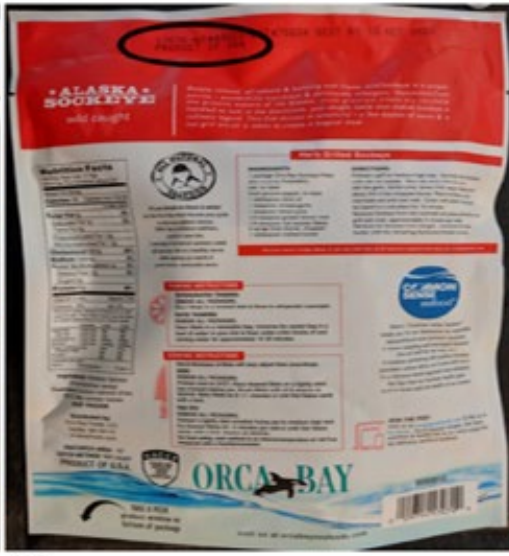

(B)

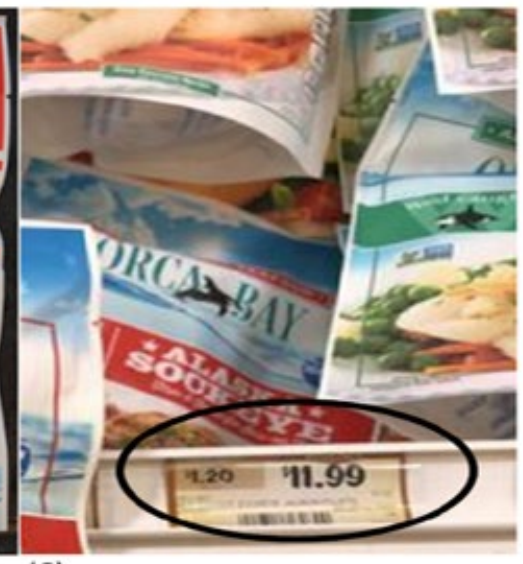

(C)

Figure 4. Example of frozen seafood packaging with COOL, species name, and net weight declared.

(A) Front of package declares procurement method ("Wild Caught"), species name ("Sockeye"), and net weight (10 oz). (B) Back of package declares country of origin ("Product of USA"). (C) In-store display information with the price of the product.

\subsection{Deglazing and net weight determination}

The net drained weight of each sample was determined according to the AOAC official method 963.18 (a) (NFI, 2016). The fish samples were removed from the $-20^{\circ} \mathrm{C}$ freezer, and the net weight on the package was noted. Next, the fish was removed from the packaging, and the initial weight was collected using a MonoBlock SB32000 Weighing Balance (Mettler, Toledo). The contents were placed under a gentle spray of cold water using a nozzle (Peerless, PRL102, China). The fish was then agitated and sprayed with water until all the ice glaze was removed. Next, the fish was transferred to a circular No. 8 sieve (Cole-Parmer, Mentor, Ohio) inclined at an angle of $17-20^{\circ}$ for draining. Fillets weighing $0.91 \mathrm{~kg}$ or less were drained in a sieve with an 8 in. $(20 \mathrm{~cm})$ diameter and fillets weighing more than $0.91 \mathrm{~kg}$ were drained in a sieve with a $12 \mathrm{in}$. $(30 \mathrm{~cm})$ diameter. After draining for $2 \mathrm{~min}$, the fish was immediately transferred to a scale to obtain the deglazed weight. Samples that exceeded the maximum allowed variance (MAV), according to the National Institute of Standards and Technology (NIST) standards, were deemed to be short-weighted (NIST, 2011). 
3.5 DNA barcoding of fish fillets

\subsubsection{DNA extraction and quantification of fish fillets}

Following deglazing, the samples were placed in the fridge for $2-4 \mathrm{~h}$ to allow for partial thawing. A tissue sample ( $\sim 10 \mathrm{mg})$ from the interior of the fish was aseptically removed and placed in a sterile $1.5 \mathrm{~mL}$ microcentrifuge tube for DNA extraction (Figure 5). The remainder of the fillet was stored at $-20^{\circ} \mathrm{C}$. DNA extraction was conducted using a DNeasy Blood and Tissue kit (Qiagen, Hilden, Germany), spin-column protocol, with modifications described in Liou et al. (2020). Lysis was carried out at $56{ }^{\circ} \mathrm{C}$ with shaking at $300 \mathrm{rpm}$ for $3 \mathrm{~h}$ in an Eppendorf TheromoMixer C (Hamburg, Germany). DNA was eluted into $100 \mu 1$ of preheated AE buffer (37 $\left.{ }^{\circ} \mathrm{C}\right)$. A Biophotomer Plus (Eppendorf) was used to measure the concentration of the DNA extracted. DNA extracts with concentrations greater than $30 \mathrm{ng} / \mu 1$ were diluted with AE buffer to $\leq 30 \mathrm{ng} / \mu \mathrm{l}$ (Moore et al., 2012). The extracted DNA was stored at $-20{ }^{\circ} \mathrm{C}$ until use in PCR (up to $1 \mathrm{wk})$. A reagent blank with no fish was included alongside each set of DNA extractions to serve as a negative control. 


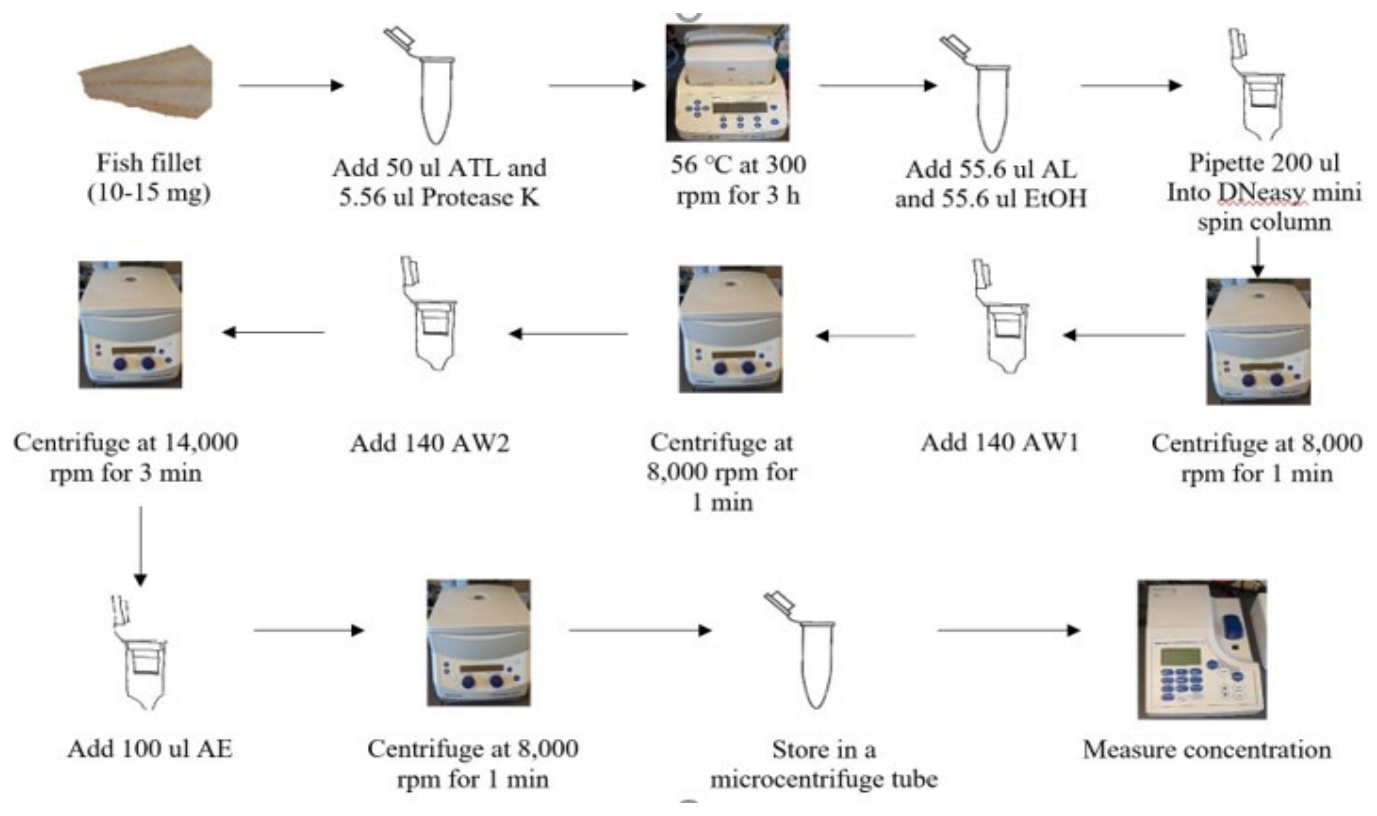

Figure 5. DNA extraction from fish fillets.

\subsubsection{PCR amplification and confirmation}

All DNA extracts underwent full barcoding (655 bp) of the COI gene, as described previously (Liou et al., 2020; Moore et al., 2012). Each reaction tube contained $12.5 \mu 1$ 10\% trehalose, $8.0 \mu 1$ molecular grade $\mathrm{H}_{2} \mathrm{O}$, 0.5 OmniMix HS Lyophilized PCR Master Mix bead (Cepheid, Sunnyvale, CA), 0.25 ul of each $10 \mathrm{uM} \mathrm{COI}$ full barcode primer and $2.0 \mu 1$ of DNA template $(\leq 30 \mathrm{ng} / \mu \mathrm{l})$. Thermal cycling was carried out at $94{ }^{\circ} \mathrm{C}$ for $2 \mathrm{~min}$; followed by 35 cycles at $94{ }^{\circ} \mathrm{C}$ for $30 \mathrm{sec}, 55^{\circ} \mathrm{C}$ for $40 \mathrm{sec}$ and $72{ }^{\circ} \mathrm{C}$ for $1 \mathrm{~min}$; then a final extension at $72{ }^{\circ} \mathrm{C}$ for 10 min. Samples that could not be identified using full DNA barcoding underwent mini-barcoding as described in Liou et al. (2020), with each reaction tube containing $22.0 \mu 1$ molecular grade water, 0.5 OmniMix HS Lyophilized PCR Master Mix bead, $0.50 \mu 1$ of each $10 \mathrm{uM} \mathrm{COI} \mathrm{mini-}$ barcode SH-E primer and $2.0 \mu \mathrm{l}$ of DNA template. Thermal cycling was carried out at $95^{\circ} \mathrm{C}$ for 5 min; followed by 35 cycles of $94^{\circ} \mathrm{C}$ for $40 \mathrm{~s}, 46^{\circ} \mathrm{C}$ for $1 \mathrm{~min}$, and $72^{\circ} \mathrm{C}$ for $30 \mathrm{~s}$; with a final extension of $72{ }^{\circ} \mathrm{C}$ for 5 mins. An Eppendorf Mastercycler nexus gradient was used for all thermal cycling reactions. 
Amplification of PCR products was confirmed using a pre-cast 2\% agarose E-Gel (Life Technologies, Carlsbad, CA) run for 15 min on E-Gel iBase Power System (Life Technologies), as described by Liou et al. (2020). The wells were loaded with $4 \mu \mathrm{l}$ PCR product and $16 \mu 1$ sterile deionized water. Image results were taken using a FOTO/Analyst Express, Transilluminator FBDLT-88, and visualized with FOTO/Analyst PCImage (Fotodyne, Hartland, WI).

\subsubsection{DNA sequencing}

PCR products were purified with ExoSAP-IT (Affymetrix, Santa Clara, CA) according to instructions by the manufacturer. The samples were sequenced bidirectionally with M13 primers at the GenScript facility (Piscataway, NJ). The samples were sequenced using BigDye Terminator v3.1 Cycle Sequencing Kit (Life Technologies) and a 3730xl Genetic Analyzer (Life Technologies).

The raw data obtained from sequencing were assembled and edited using Geneious R7 (Biomatters, Ltd., Auckland, New Zealand). Consensus sequences were trimmed to the target region for the 655 bp full-length COI barcode (Handy et al., 2011) and the 226 bp SH-E minibarcode (Shokralla et al., 2015). Full-length COI barcodes were considered successful if they passed QC parameters described in Handy et al. (2011): bidirectional sequences with $\geq 500 \mathrm{bp}$ and $<2 \%$ ambiguities or single reads with $\geq 500 \mathrm{bp}$ and $\geq 98 \%$ high-quality bases. The COI results were considered successful if they passed the QC parameters utilized by Pollack et al. (2018): bidirectional sequences with $\geq 76 \%$ of the target length and $<2 \%$ ambiguities or single reads with $\geq 76 \%$ of the target length and $\geq 98 \%$ high-quality bases. The full COI and minibarcode SH-E sequences were queried against the Species Level Barcode Records in the Barcode 
of Life Database (BOLD) were queried against GenBank using the Basic Local Alignment Search Tool (BLAST). The common name and acceptable market names for each identified species were determined according to the FDA Seafood List (FDA, 2020).

\section{Results and discussion}

\subsection{Country of origin labeling compliance}

COOL requires retailers to provide consumers with both the country of origin (COO) and the method of production (MOP) legibly in a conspicuous location (USDA, 2020). The samples examined in this study had a high level of COOL compliance, with 110 out of 111 samples (99\%) compliant with COOL. The only sample (A045) that was not COOL compliant was labeled "Hokkai cod fillet." This sample displayed the country of origin (China); however, it did not indicate the production method. Without the production method, this sample is considered noncompliant with COOL. Unlike most of the other samples, this sample had a sticker-style label that may have been printed at the retail outlet and placed on the bag. The majority $(n=107)$ of the COOL compliant samples were in packages with labels that appeared to have been applied by the processors and/or they had a printed card with COOL information placed inside the packaging. Overall, the 111 samples declared 18 different countries of origin, with the top seven countries being China $(n=39)$, USA $(n=20)$, Vietnam $(n=17)$, Taiwan $(n=6)$, Indonesia $(n=$ 5), Peru $(\mathrm{n}=5)$, and Ecuador $(\mathrm{n}=3)$. Singapore, Norway, New Zealand, Poland, and Spain were each declared by two products, while Malaysia, Maldives, Thailand, Brazil, Chile, and Greenland were each declared by one product. Among the 110 samples that declared a production method, most of the fish were labeled as wild or wild-caught $(\mathrm{n}=80)$, while the remaining samples $(\mathrm{n}=30)$ were labeled as farmed or farm-raised. 
The country of origin and procurement information for 77 of the frozen fish samples was found on the back of the package below the nutrition label in relatively small type. In 29 samples, the COOL information was clearly displayed on the front of the package, commonly highlighting procurement method over origin and featuring wild products rather than farmraised. In 5 samples, the COOL information was on a side panel of the package under the nutritional label. In addition to the COOL information on the packaging, other claims noted on the packages included: " $100 \%$ sustainably sourced", "non-GMO project certified," "good source of omega 3" and "sushi grade, excellent gluten-free source of protein, responsibly sourced." These results were similar to a study conducted by Lagasse et al. (2014), which reported that the COOL information on frozen seafood packages was often difficult to find and was typically found on the back of the package in small type under the nutrition label. They also reported similar claims on the packaging as those found in the current study, such as "sustainably sourced" and "GMO certified."

The high level of COOL compliance (99\%) reported in this study is similar to a previous study by Lagasse et al. (2014) conducted in Baltimore city that found the majority (96.2\%) of 628 samples of fresh and frozen fish examined were compliant with COOL. In comparison, national surveillance on COOL compliance conducted by the Agricultural Marketing Service (AMS) in 2016 reported 90\% COOL compliance among 79,928 fish and shellfish products examined at $>3000$ retail store facilities across the United States (Liou et al., 2020). In the study conducted by Lagasse et al. (2014), 52.5\% of samples were imported, $44.5 \%$ were domestic, $1.9 \%$ were mixed, and $1.1 \%$ were not labeled. In comparison, a higher proportion $(75.6 \%)$ of the samples examined in the current study were imported, $18.9 \%$ were domestic, and $5.4 \%$ were mixed. With regards to production method, over half (53.7\%) of the samples collected by 
Lagasse et al. (2014) were declared to be wild-caught, 43.6\% were declared as farmed, and 2.7\% did not declare a production method. In the current study, a higher percentage $(72.1 \%)$ of samples were declared to be wild-caught, while $27.0 \%$ were declared as farmed and $0.9 \%$ did not declare a production method. Regardless of the differences in the declared country of origin and production method for samples examined in each of these studies, the COOL compliance rate remained high.

Previous studies conducted in Southern California have reported lower rates of COOL compliance (41-77\%) among fish purchased at grocery stores (Bosko et al., 2018; Liou et al., 2020). For example, Liou et al. (2020) reported that about $77 \%$ of fresh or thawed (previously frozen) fish purchased at 30 grocery stores were compliant with COOL, while Bosko et al. (2018) reported that only $41 \%$ of 32 fresh/frozen catfish samples purchased from 40 grocery stores were compliant with COOL. In comparison, all four catfish products examined in the current study were compliant with COOL. One difference between the current study and previous studies conducted in Southern California is that this study focused solely on prepackaged frozen fish, while previous studies examined only fresh/thawed fish (Liou et al., 2020) or a combination of fresh/thawed and frozen fish (Bosko et al., 2018). For the majority of prepackaged frozen fish, the label is applied by the processor before it arrives at the retail outlet. In comparison, fresh/thawed fish is typically displayed at grocery store seafood counters and the retailer is responsible for proper labeling of the product. The different rates of COOL compliance indicate that there may be some confusion, lack of training, and/or lack of information provided at the retail level for the proper labeling of seafood for the country of origin and production method. 
Of the 111 samples, five were labeled as being caught in a different country from the production country. For example, products labeled as "wild Alaskan flounder" (A081), "wild caught Alaskan cod" (A110), and "wild caught Russia" pink salmon (A005) were all declared to be products of China. An Atlantic salmon product (A024) was labeled as "farm raised in Norway" and "prepared and packed in the USA," while another product labeled as "wild-caught mahi mahi" (A101) had declarations of "product of Ecuador" and "packed in USA." Under the COOL regulations, when fish are procured in US waters and then processed in foreign countries, that foreign country of processing must appear as the country of origin on the packaging (USDA, 2020). Processing from foreign countries includes filleting and packaging the cuts of fish for grocery stores. In these cases, retailers are permitted to advertise the location where the fish was caught, such as Alaska, along with the country of origin where processing occurred (USDA, 2020). However, the importer must be able to provide documentation that the salmon was caught in Alaskan waters.

\subsection{Short weighting}

A short-weighted product is one that has a net weight that is less than the net weight declared on the label, thus overcharging consumers for less product. Short weighting was detected in 10 of the 111 fish fillets (9.0\%) (Table 5), based on NIST standards for the maximum allowable weight variation. Six of the 13 categories of fish tested had at least one sample that was short weighted, including pollock $(n=3 / 7)$, flounder $(n=3 / 7), \operatorname{cod}(n=1 / 15)$, tilapia $(n=1 / 15)$, swai $(n=1 / 8)$, and swordfish $(n=1 / 2)$. The average deglazed weight/declared weight for all 111 samples was $101.2 \pm 5.9 \%$. When looking specifically at short-weighted fish, the average deglazed weight/declared weight was $87.1 \pm 0.9 \%$, with pollock at $76.0 \%$, flounder at $91.3 \%$, cod at $89.4 \%$, tilapia at $92.1 \%$, swai at $92.4 \%$ and swordfish at $94.9 \%$. An additional 
15 samples had a deglazed weight that was less than the declared weight but was within the allowable variation and, therefore, not short-weighted. The most extreme case of short weighting occurred with a fish labeled as pollack; whose deglazed weight was only $66.6 \%$ of the declared weight. This sample was purchased for US $\$ 6.71 / \mathrm{kg}$, meaning that consumers were overcharged US $\$ 2.21 / \mathrm{kg}$ (Table 5). The overall average price that consumers were overcharged for the shortweighted samples was US $\$ 1.14 \pm 0.74 / \mathrm{kg}$. Among the fish categories, the average amounts overcharged were as follows: US $\$ 1.71 \pm 0.44 / \mathrm{kg}$ for pollock $(\mathrm{n}=3), \$ 0.86 \pm 0.88 / \mathrm{kg}$ for flounder $(\mathrm{n}=5)$, US $\$ 1.63 / \mathrm{kg}$ for $\operatorname{cod}(\mathrm{n}=1)$, US $\$ 1.39 / \mathrm{kg}$ for tilapia $(\mathrm{n}=1)$, US $\$ 0.84 / \mathrm{kg}$ for swai $(\mathrm{n}=1)$ and US $\$ 0.09 / \mathrm{kg}$ for swordfish $(\mathrm{n}=1)$. Of the ten samples that were short-weighted, six were also determined to be overglazed (discussed below). 
Table 5. Net weight determination results and \% glaze for the fish samples in this study determined to be overglazed (>10\% glaze) and/or shortweighted. Samples are listed in descending order based on the percent glaze.

\begin{tabular}{|c|c|c|c|c|c|c|c|c|c|c|c|}
\hline Sample \# & Category & Product description & $\begin{array}{l}\text { Product } \\
\text { price per } \\
\mathrm{kg}(\mathrm{US} \\
\$ / \mathrm{kg}) \\
\end{array}$ & $\begin{array}{l}\text { Net weight } \\
\text { on } \\
\text { package } \\
(\mathrm{g})\end{array}$ & $\begin{array}{l}\text { Glazed } \\
\text { weight } \\
\text { (g) }\end{array}$ & $\begin{array}{l}\text { Deglazed } \\
\text { weight }(\mathrm{g})\end{array}$ & $\begin{array}{l}\text { Percent } \\
\text { glaze } \\
(\%)\end{array}$ & $\begin{array}{l}\text { Maximum } \\
\text { allowable } \\
\text { variation }^{\mathrm{a}}(\mathrm{g})\end{array}$ & $\begin{array}{l}\text { Detected } \\
\text { variation }^{\mathrm{b}} \\
(\mathrm{g})\end{array}$ & $\begin{array}{l}\text { Deglazed } \\
\text { weight/decl } \\
\text { ared weight } \\
(\%)\end{array}$ & $\begin{array}{l}\text { Price of } \\
\text { glaze (US } \\
\$ / \mathrm{kg})^{\mathrm{c}}\end{array}$ \\
\hline A050 & pollock & pollack fillet wild & 6.71 & 1016 & 1033 & 677 & 34.5 & 35.3 & 339 & 66.6 & 2.21 \\
\hline A035 & pollock & $\begin{array}{l}\text { pollock fillets wild } \\
\text { caught premium fillets }\end{array}$ & 8.80 & 454 & 493 & 374 & 24.1 & 19.9 & 80 & 82.4 & 1.54 \\
\hline A053 & pollock & pollock fillet & 6.59 & 1012 & 1037 & 799 & 23.0 & 35.3 & 213 & 79.0 & 1.39 \\
\hline A038 & flounder & $\begin{array}{l}\text { flounder fillets wild } \\
\text { caught premium fillets } \\
\text { individually vacuumed }\end{array}$ & 13.21 & 454 & 487 & 381 & 21.8 & 19.9 & 73 & 83.9 & 2.13 \\
\hline A034 & cod & cod fillets & 15.41 & 454 & 474 & 406 & 14.4 & 19.9 & 48 & 89.4 & 1.63 \\
\hline $\mathrm{A} 064^{\mathrm{d}}$ & flounder & $\begin{array}{l}\text { flounder fillets wild } \\
\text { caught }\end{array}$ & 10.32 & 680 & 770 & 672 & 12.7 & 25.4 & 8 & 98.8 & 0.12 \\
\hline A081 & flounder & wild Alaskan flounder & 13.65 & 1600 & 1749 & 1545 & 11.7 & 49 & 55 & 96.6 & 0.46 \\
\hline A059 & swai & swai fillets & 11.00 & 462 & 467 & 427 & 8.6 & 19.9 & 39 & 92.4 & 0.84 \\
\hline A098 & tilapia & $\begin{array}{l}\text { farm-raised tilapia } \\
\text { fillets }\end{array}$ & 17.63 & 907 & 910 & 835 & 8.2 & 31.7 & 72 & 92.1 & 1.39 \\
\hline A015 & flounder & flounder skinless fillets & 11.33 & 454 & 462 & 425 & 8.0 & 19.9 & 29 & 93.6 & 0.73 \\
\hline A001 & swordfish & $\begin{array}{l}\text { swordfish steaks (on } \\
\text { front) ahi tuna (on } \\
\text { back) }\end{array}$ & 17.61 & 412 & 411 & 391 & 4.9 & 18.1 & 21 & 94.9 & 0.09 \\
\hline
\end{tabular}


When seafood products are short-weighted, the economic losses to the consumers are in proportion to the difference between the actual weights and the labeled weight of the product (Upton, 2015). A previous U.S. seafood industry survey on the costs of short weighting conducted between 2005 and 2009 asked survey respondents to estimate the percentage of product purchased at the wholesale (import) level that was less than $100 \%$ of the net weight (Santos et al., 2010). The survey respondents estimated that a $20-40 \%$ of pollock purchased was less than $100 \%$ of the declared net weight, with an estimated net weight of $85-93 \%$ for fillets. The estimated cost of glaze for the short-weighted pollock imported during this time period was between US $\$ 0.18$ and $0.38 / \mathrm{kg}$ (Santos et al., 2010), translating to an estimated cost per year of US \$7.4-13.9 million. In comparison, pollock samples in the current study that were less than $100 \%(n=5 / 7)$ of the declared weight had a wider range for the cost of glaze (US $\$ 0.01$ to $\$ 2.21 / \mathrm{kg}$ ). The cost of glaze for the one short-weighted tilapia sample in the current study was US $\$ 1.39 / \mathrm{kg}$, which is within the estimated range reported by Santos et al. (2010) for tilapia fillets of US $\$ 0.25$ to $\$ 2.22 / \mathrm{kg}$. The other categories of short-weighted samples from the current study had the average glaze price as follows: flounder US $\$ 0.35$ to $\$ 0.73 / \mathrm{kg}$, swordfish US $\$ 0.09 / \mathrm{kg}$, cod US $\$ 1.63 / \mathrm{kg}$, and swai US $\$ 0.84 / \mathrm{kg}$. However, Santos et al. (2010) did not provide short weighting or cost of glaze estimates for these categories of fish. Overall, it has been estimated that if $2 \%$ of the declared weight of seafood purchased by US consumers was ice, the annual loss to consumers would be about $\$ 1.6$ billion (Sefcik, 2011), suggesting that a small percentage of fraud could add up to billions of dollars lost.

\subsubsection{Percent glaze}

The average percent glaze for all 111 fish samples was $4.97 \% \pm 5.48 \%$, and the majority of fish samples $(\mathrm{n}=103)$ had glaze at levels of $10 \%$ or less (Figure 6). Seven samples had $>10 \%$ 
glaze (Table 6) and were considered overglazed based on the previously recommended adequate glazing amount of 6-10\% (Vanhaecke et al., 2010). Similarly, Vanhaecke et al. (2010) reported that the majority of fish samples examined in their study had glaze levels of $10 \%$ or less, with $5.6 \%$ of samples having over $12 \%$ glaze. However, it is important to point out that there are no regulations regarding the percentage of glaze that can be used on frozen fish. The highest percent glaze was found in 3 pollock samples, which had 34.5\%, 24.1\%, and 23.0\% glaze (Table 6). Of the 13 fish categories examined, pollock had the highest average percent glaze at 14.7\% (34.5\% max) with an average product cost of US $\$ 7.23 / \mathrm{kg}$, followed by flounder at $10.16 \%$ glaze $(21.8 \%$ max, US $\$ 11.57 / \mathrm{kg})$, halibut at $7.1 \%(10.0 \% \max$, US $\$ 43.50 / \mathrm{kg})$, whiting at $6.3 \%(8.9 \% \max$, US $6.41 / \mathrm{kg})$, salmon at $5.6 \%(9.3 \% \max$, US $\$ 24.48 / \mathrm{kg})$ and cod at $5.1 \%(14.4 \% \max$, US $\$ 19.03 / \mathrm{kg}$ ). The other fish categories had average glaze below 5\%. In comparison, the highest average amount of glaze reported by Vanhaecke et al. (2010) was observed in flounder at 6-14\% (EU $€ 7.80 / \mathrm{kg}$ or US $\$ 8.74 / \mathrm{kg}$ ) followed by pollack with $6-10 \%$ (EU $€ 6.30$ or US $\$ 6.84$ ).

When comparing samples based on procurement method, fish labeled as wild-caught had higher average glaze levels $(5.6 \%, \max =34.5 \%)$ compared to fish labeled as farm-raised (average $=3.1 \%, \max =9.7 \%)$. Furthermore, all seven samples that were considered overglazed were labeled as wild-caught. The increased glaze levels on the wild samples compared to the farmed samples could be due to differences in processing. After fish are caught on fishing vessels, the fish is frozen and then glazed as soon as possible to prevent dehydration and oxidation decay of the fish (Gucker et al., 1986). When in the hands of the processor, the glaze is checked periodically and replaced when necessary. Therefore, the increased amount of glaze observed for wild-caught fish samples could be due to additional glaze applied by the processors 
(Gucker \& Johnson, 1986). In comparison, some aquaculture facilities have their own processing plant attached (Aquaculture, 2019).

Table 6. Percent glaze based on fish category

\begin{tabular}{lllll}
\hline Fish category & $\begin{array}{l}\text { No. of samples } \\
\text { per category }\end{array}$ & $\begin{array}{l}\text { Average \% } \\
\text { glaze (\%) }\end{array}$ & $\begin{array}{l}\text { Maximum \% } \\
\text { glaze (\%) }\end{array}$ & $\begin{array}{l}\text { Average } \\
\text { product price } \\
\text { per kg (US \$) }\end{array}$ \\
\hline catfish & 4 & 2.8 & 6.4 & 14.45 \\
cod & 15 & 5.0 & 14.4 & 19.03 \\
flounder & 7 & 10.2 & 21.8 & 11.57 \\
halibut & 7 & 7.2 & 10.0 & 43.50 \\
mahi mahi & 10 & 4.2 & 7.8 & 21.77 \\
orange roughy & 2 & 0.7 & 2.2 & 26.80 \\
pollock & 7 & 14.7 & 34.5 & 7.23 \\
salmon & 15 & 5.6 & 9.3 & 24.48 \\
swai & 8 & 4.8 & 9.7 & 11.19 \\
swordfish & 2 & 3.4 & 4.9 & 20.93 \\
tilapia & 15 & 2.0 & 9.3 & 15.04 \\
tuna & 15 & 0.1 & 2.6 & 19.82 \\
whiting & 4 & 6.3 & 8.9 & 6.41 \\
\hline overall & 111 & 5.2 & 34.5 & 18.63 \\
\hline
\end{tabular}

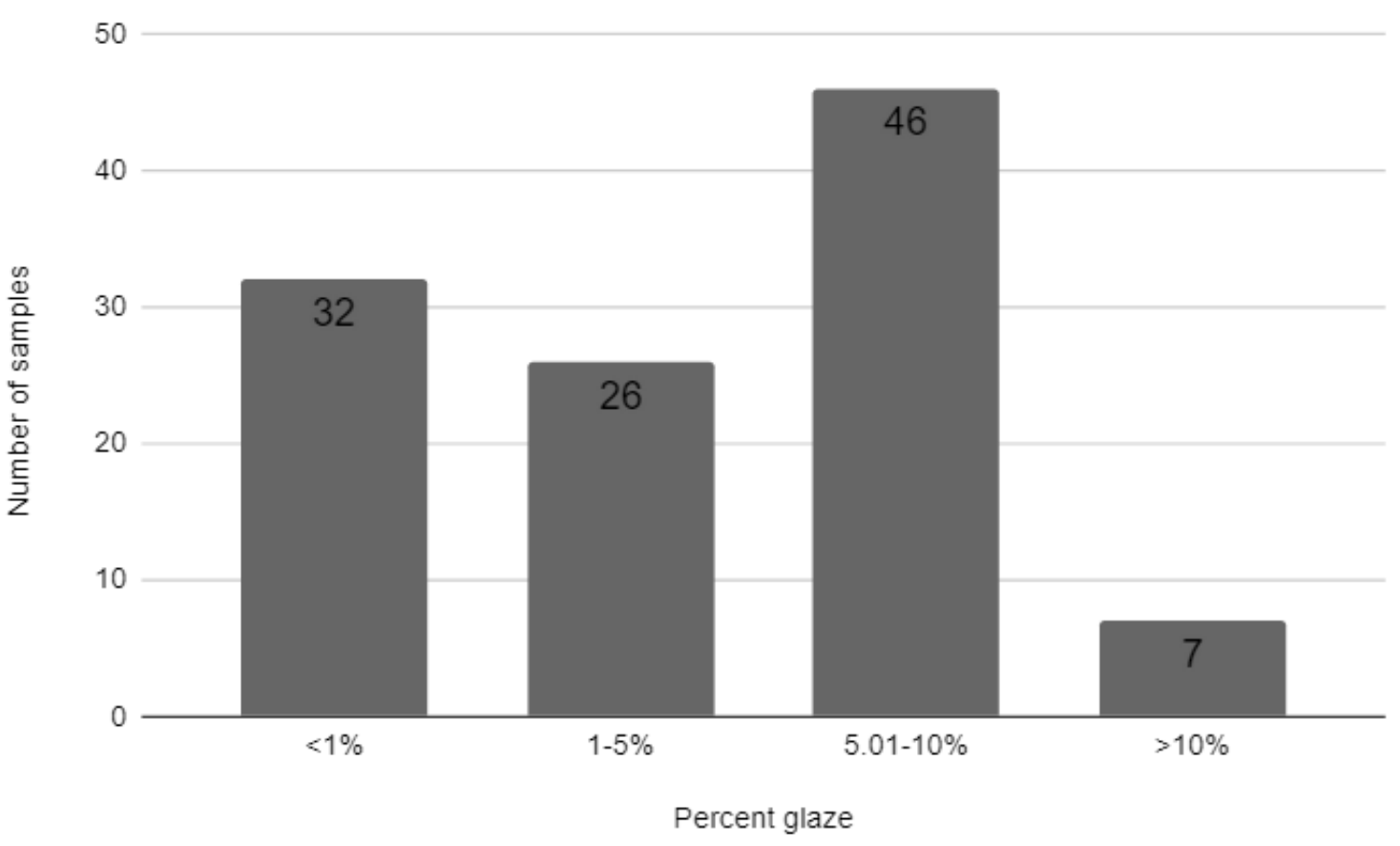

Figure 6. Percent glaze measured on prepackaged frozen fish fillets $(n=111)$. 
The varying levels of glaze observed in this study could also be due to differences in glazing methods (dipping vs. spraying). The amount and uniformity of glaze are difficult to control because they depend on the product type, glaze temperatures, size and surface area, and glazing time (Soares, 2016). While it is difficult to obtain consistent levels of glaze, establishment of a standardized target range for glaze $\%$ on frozen seafood products may be more achievable. Additional research into glazing procedures and best practices is warranted in order to provide evidence-based recommendations for the seafood industry. Furthermore, increased inspections and enforcement surrounding short weighted seafood products should be considered as a potential means to reduce this practice (Santos et al., 2010).

4.3 Species authentication and acceptable market names

All 111 prepackaged frozen fish collected for this study were identified with at least one of the COI barcoding methods (full or mini barcoding) (Table 7). The majority of samples ( $\mathrm{n}=$ 106) were identified using the COI full barcode primer set, and the remaining five samples were identified using the COI mini-barcoding primer set. Each sample had at least one top species match in BOLD with $>98 \%$ genetic similarity, except for one sample labeled as cod that had a top mini-barcode species match to haddock (Melanogrammus aeglefinus) at 96\% in GenBank (no sequence match in BOLD). The sequence coverage for the sample identified as haddock included the entire mini-barcode (226 bp); however, the quality was low $(\mathrm{HQ} \%=27.9 \%)$, which may explain the relatively low sequence similarity. The other four samples that were only successful with mini barcoding were identified as Atlantic salmon (Salmo salar), walleye pollock (Gadus chalcogrammus), Pacific cod (Gadus macrocephalus)/Greenland cod (Gadus ogac) and yellowfin sole (Limanda aspera). Of the 111 samples, 67 were identified to the species level, meaning that they had a top genetic match to a single species (Table 7). This 
included all samples in the following categories: salmon $(n=15)$, mahi-mahi $(n=10)$, swai $(n=$ 8), pollock ( $\mathrm{n}=7)$, orange roughy $(\mathrm{n}=2)$ and swordfish $(\mathrm{n}=2)$, as well as some samples of cod ( $\mathrm{n}=5 / 15)$, tuna $(\mathrm{n}=5 / 15)$, flounder $(\mathrm{n}=5 / 7)$, halibut $(\mathrm{n}=4 / 7)$, catfish $(\mathrm{n}=3 / 4)$ and whiting $(\mathrm{n}=$ 1/4). Among the 44 samples not identified to the species level with COI full or mini-barcoding, 40 were identified to the genus level (i.e., showed a top match to multiple species from the same genus). These included all samples of $\operatorname{cod}(n=10)$, the majority of samples of tilapia $(n=11 / 15)$, tuna $(n=10 / 15)$, and whiting $(n=3 / 4)$, and a few samples of catfish $(n=1 / 4)$, flounder $(n=2 / 7)$, and halibut $(n=3 / 7)$ (Table 7). Four tilapia samples showed a top genetic match to species from multiple genera in the Cichlid family (Oreochromis and Coptodon). Tilapia is difficult to identify to the species level because it is commonly cross-bred and hybridized species cannot be differentiated with COI DNA barcoding (Dunz et al., 2013). Several tuna species are closely related and are known to be difficult to differentiate based on COI DNA barcoding (Liou et al., 2020; Pollack et al., 2018). 
Table 7. Combined results of full and mini-DNA barcoding for fish fillets tested in this study (n $=111$ ). Values are displayed as the number count.

\begin{tabular}{|c|c|c|c|c|c|}
\hline Category & $\begin{array}{l}\text { Number } \\
\text { of } \\
\text { samples }\end{array}$ & $\begin{array}{l}\text { Identified } \\
\text { to species } \\
\text { level }\end{array}$ & $\begin{array}{l}\text { Identified to genus } \\
\text { level }\end{array}$ & $\begin{array}{l}\text { Identified to } \\
\text { multi-genus } \\
\text { level }\end{array}$ & $\begin{array}{l}\text { Samples } \\
\text { with species } \\
\text { mislabeling }\end{array}$ \\
\hline catfish & 4 & 3 & 1 (Ictalurus) & - & 0 \\
\hline $\operatorname{cod}$ & 15 & 5 & 10 (Gadus) & - & 1 \\
\hline flounder & 7 & 5 & $\begin{array}{l}2 \text { (Limanda, } \\
\text { Pleuronectes) }\end{array}$ & - & 0 \\
\hline halibut & 7 & 3 & 3 (Hippoglossus) & - & 1 \\
\hline mahi mahi & 10 & 10 & - & - & 0 \\
\hline $\begin{array}{l}\text { orange } \\
\text { roughy }\end{array}$ & 2 & 2 & - & - & 0 \\
\hline pollock & 7 & 5 & - & - & 2 \\
\hline salmon & 15 & 15 & - & - & 0 \\
\hline swai & 8 & 8 & - & - & 0 \\
\hline swordfish & 2 & 2 & - & - & 0 \\
\hline tilapia & 15 & - & 11 (Oreochromis) & $\begin{array}{l}4 \\
\text { Oreochromis, } \\
\text { Coptodon) }\end{array}$ & 0 \\
\hline tuna & 15 & 5 & 9 (Thunnus) & - & 1 \\
\hline whiting & 4 & 1 & 3 (Merlucius) & - & 0 \\
\hline Overall & 111 & 63 & 39 & 4 & 5 \\
\hline
\end{tabular}

${ }^{a}$ Refers to samples with species substitution or unacceptable market name.

${ }^{\mathrm{b}}$ One flounder sample had top genetic matches to multiple Limanda spp. and one sample matched multiple Pleuronectes spp.

The majority of fish (95.5\%) were found to be correctly labeled with regards to species and/or acceptable market name. Species substitution was detected in two of the 111 samples, and an additional three samples had unacceptable market names (Table 8). The two substituted samples consisted of (1) Kamchatka flounder (Atheresthes evermanni) mislabeled as halibut and (2) haddock (Melanogrammus aeglefinus) mislabeled as cod. Halibut labeling in the U.S. is governed by a specific regulation 21 CFR 102.57 , stating that only two species can use the "halibut" label, the Atlantic halibut (Hippoglossus hippoglossus), and the Pacific halibut (Hippoglossus stenolepis). Halibut was the most expensive overall fish category, however, this sample (A069) was priced at US $\$ 8.79 / \mathrm{kg}$ and was the cheapest halibut sample purchased in this study. The price of the mislabeled sample was similar to the average price of flounder samples 
purchased in this study (\$11.57). Therefore, this substitution event may have been unintentional and is possibly a result of confusion regarding proper species labeling. Although the fillets of Kamchatka flounder and halibut do not look alike (Figure 7), Kamchatka flounder and Pacific halibut are both native to the North Pacific Ocean (Fishbase, 2020). However, similar to the results of this study, previous studies have also reported the mislabeling of flounder samples as halibut. For example, Willette et al. (2017) found that $89 \%$ of "halibut" sushi samples collected in a market survey in Los Angeles, CA, were flounder (Paralichthys spp.). An Oceana study investigating grocery stores and sushi restaurants in Northern California reported the mislabeling of 4 "halibut" samples identified as flounder (Paralichthys californicus) (Warner et al., 2013).

The mislabeling of haddock as cod does not appear to have been economically motivated, as the price of the mislabeled haddock sample was US $\$ 15.41 / \mathrm{kg}$, and the average price of cod in this study was US $\$ 18.96 / \mathrm{kg}$. Both haddock and cod are similar in appearance, and they are known to swim together in the same regions, so the haddock sample may have been caught in the same mass net as cod and mislabeled as cod (UCD, 2010). Another reason for the mislabeling of haddock as cod could be because of quotas fishers are given for the year. If a fisherman reaches their quota of cod for the year they must either stop fishing or purchase more quotas of cod. To get around this, fishers could mislabel cod as haddock, as reported previously in the US (Crowell et al., 2018; Moore, 2019). A previous market survey conducted in Europe found similar inconsistencies, with a cod sample purchased from a European grocery store identified as haddock (M. aeglefinus) (Miller et al., 2010).

Each of the five samples was purchased at different stores, but two (A069 and A067) were from the same brand. All five of the samples that were mislabeled were advertised as wildcaught; the samples identified as pollock (A050, A067) and haddock (A034) listed China as the 
country of origin, the sample identified as flounder (A069) listed the USA, and the tuna sample (A001) declared Spain as the country of origin. 
Table 8. Samples in this study identified as being mislabeled due to species substitution or use of an unacceptable market name $(\mathrm{n}=4)$.

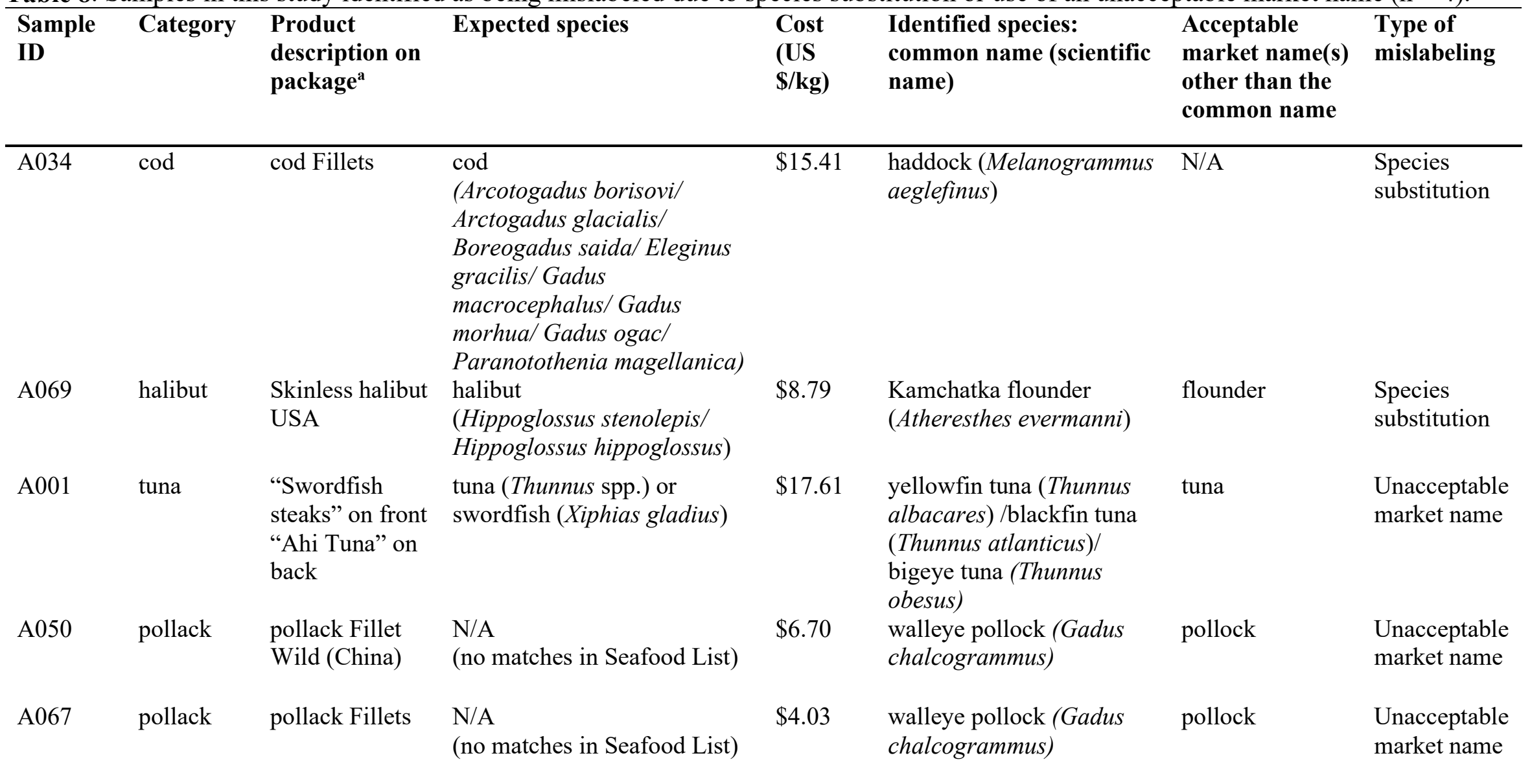

${ }^{\mathrm{a}} \mathrm{COOL}$ information not listed unless described on the packaging label 


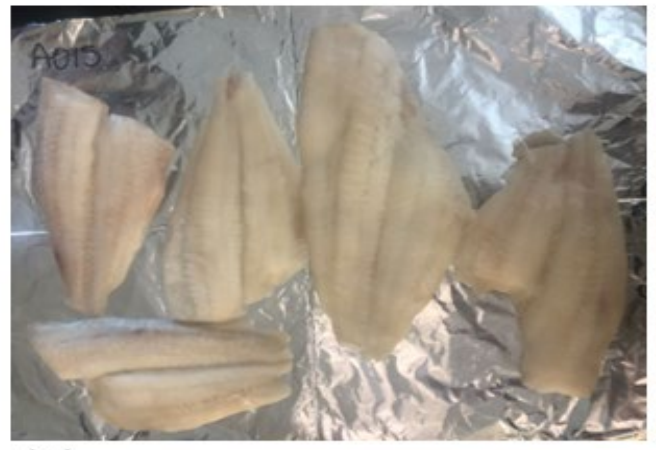

(A)

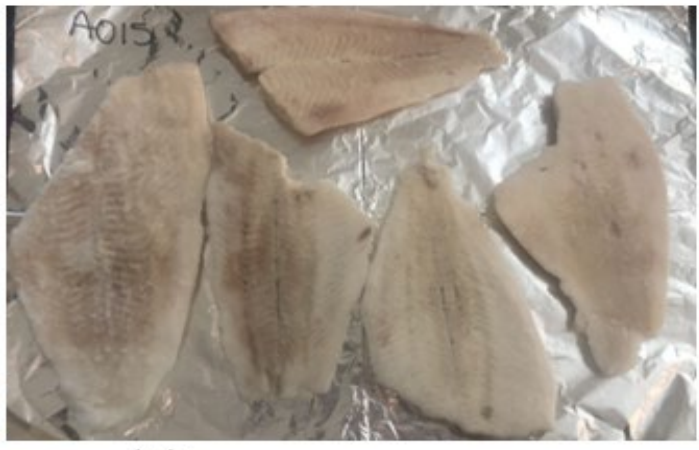

(B)

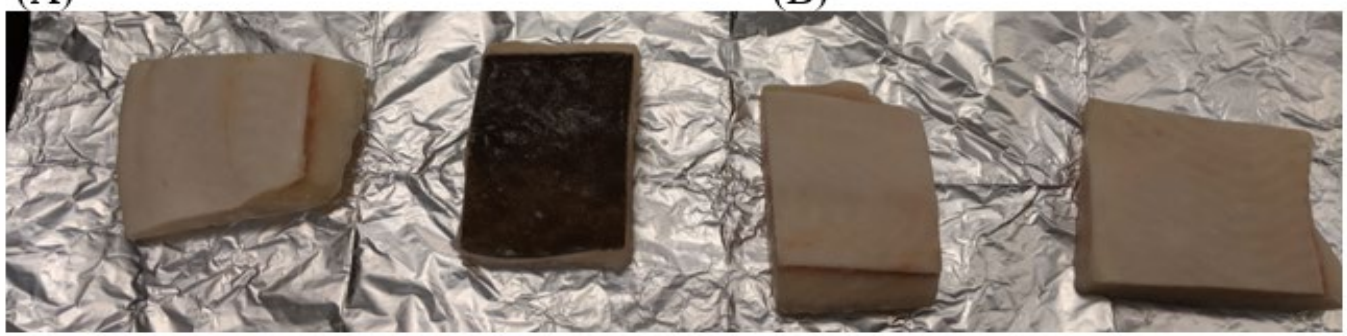

(C)

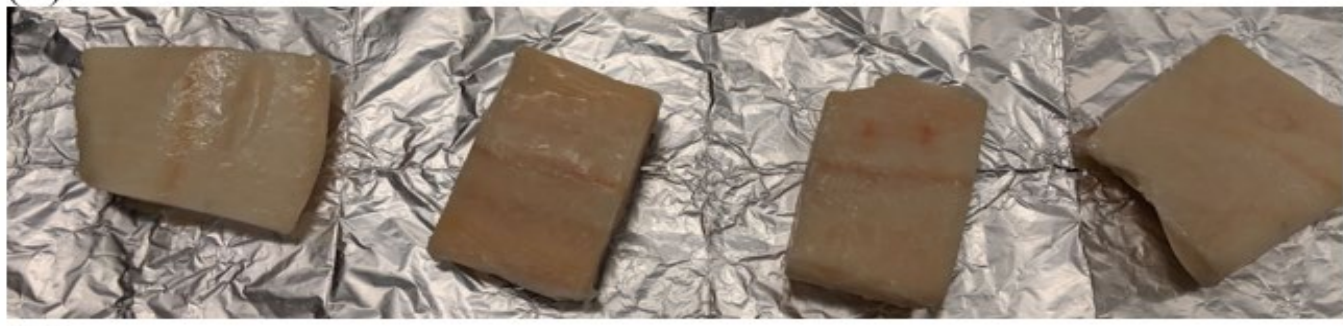

(D)

Figure 7. Top and bottom sides of the fillet cuts of (A-B) Kamchatka flounder sample A069 (Atheresthes evermanni) mislabeled as halibut and (C-D) authenticated Pacific halibut (Hippoglossus stenolepis). Note: all of the halibut samples purchased in this study were cut to a similar shape, with some having the skin attached.

With the wide variety of fish species, the use of acceptable market names is essential to identify seafood in the market (FDA, 2012). According to the FDA Seafood List, fish should be labeled by the common name or an acceptable market name to avoid misbranding. Three samples examined in this study were found to have unacceptable market names (Table 8). One sample (A001) listed both swordfish and ahi tuna on its packaging: a sticker label with the wording "swordfish steaks" was adhered to the outside of the package while a label on the inside of the package declared "ahi tuna." This sample was identified as tuna (Thunnus spp.) and was deemed to have an unacceptable market name because it was labeled with conflicting species 
names. Two additional samples were labeled as "pollack" but identified as walleye pollock (Gadus chalcogrammus). According to the FDA Seafood List, pollack is not considered an acceptable market name for any species. However, according to FishBase, "pollack" is the common name for the species Pollachius pollachius, and in other markets globally, the terms "pollack" and "pollock" are used interchangeably (Goltz, 1995; Seafish, 2014). Global differences in acceptable market names, such as this example, can lead to confusion in the labeling of fish species. In these instances, it may be preferable to include the scientific name of the species to promote transparency. Of note, in the current study, only about one third of the samples $(\mathrm{n}=35)$ stated the scientific name on the package label, either as part of the ingredient list $(\mathrm{n}=23)$ or in the product name $(\mathrm{n}=12)$.

Overall, 13 samples examined in this study had at least one labeling error associated with COOL noncompliance, species mislabeling, and/or net weight violations. Three samples (A001, A034, and A050) had multiple labeling errors, specifically net weight violation and species mislabeling. Two of these samples A050 (mislabeled pollock) and A034 (mislabeled haddock) were also overglazed. Each of these fish were purchased from different stores and different brands. However, when considering the other samples that had labeling errors and/or overglazing, there were some common themes with regards to brand names and grocery stores. For example, samples A034 (mislabeled haddock), A035 (overglazed pollock) and A038 (overglazed flounder) were from the same brand and purchased from the same store. Samples A053 (overglazed pollock) and A059 (short-weighted swai) were from the same brand and were purchased from the same chain store at two different locations; this was also the case for samples A067 (mislabeled pollock) and A069 (mislabeled flounder). 


\section{Conclusion}

This was the first study to observe glazing levels, net weights, COOL compliance, and species authentication on pre-packaged frozen fish fillets sold in grocery stores. The results of this study indicate a high level of compliance with COOL (99\%) and accurate species labeling (95.5\%) among prepackaged frozen fish. Relatively low levels of species substitution (1.8\%), and unacceptable market names $(2.7 \%)$ were observed for the samples tested in this study. Overglazing ( $>10 \%$ glaze) was observed in several samples (6.3\%), with the highest amount of glaze found in pollack/pollock samples at $34.5 \%$ glaze. However, many of the samples $(n=45)$ had between 5 and $10 \%$ glaze. Short weighting was detected in $9.9 \%$ of samples, most of which were also overglazed. However, the lack of a standardized target range for glaze $\%$ on frozen seafood products makes it difficult to prevent overglazing. Increased inspections and enforcement for short weighting violations may help to decrease this type of fraud. Further research into glazing, overglazing and short weighting of seafood is needed in order to increase our understanding of current practices and the extent of net weight violations. 


\section{References}

AMS. (2009). Mandatory Country of Origin Labeling of Beef, Pork, Lamb, Chicken, Goat Meat, Wild and Farm-raised Fish and Shellfish, Perishable Agricultural Commodities, Peanuts, Pecans, Ginseng, and Macadamia Nuts; Final Rule. Federal Register 74(10). Retrieved from https://www.regulations.gov/document?D=AMS-LS-07-0081-0815

Aquaculture, G. (2019, 2019-09-25). Where Does Farmed Seafood Come From? Retrieved from https://www.aquaculturealliance.org/blog/where-does-farmed-seafood-come-from/

BOLD. (2020). Barcode of Life data systems. retrived from https://www.boldsystems.org/

Bosko, S. A., Foley, D. M., \& Hellberg, R. S. (2018). Species substitution and country of origin mislabeling of catfish products on the U.S. commercial market. Aquaculture, 495, 715720. doi:10.1016/j.aquaculture.2018.06.052

Cline, E. (2012). Marketplace substitution of Atlantic salmon for Pacific salmon in Washington State detected by DNA barcoding. Food Research International, 45(1), 388-393. doi:10.1016/j.foodres.2011.10.043

Cohen, N. J., Deeds, J. R., Wong, E. S., Hanner, R. H., Yancy, H. F., White, K. D., . . Gerber, S. I. (2009). Public health response to puffer fish (Tetrodotoxin) poisoning from mislabeled product. J Food Prot, 72(4), 810-817. doi:10.4315/0362-028x-72.4.810

Crane, D. P., Killourhy, C. C., \& Clapsadl, M. D. (2016). Effects of three frozen storage methods on wet weight of fish. Fisheries Research, 175, 142-147. doi:10.1016/j.fishres.2015.11.022

Crowell, J. A., Chambers, K. T., Garfunkel J., Lary, E., Morrison, B., Sadro, C., \& Smith, S. (2018). Department of Justice Journal of Federal Law and Practice (Vol. 66): Department of Justice 
Dunbar, S. A., Vander Zee, C. A., Oliver, K. G., Karem, K. L., \& Jacobson, J. W. (2003). Quantitative, multiplexed detection of bacterial pathogens: DNA and protein applications of the Luminex LabMAPTM system. Journal of Microbiological Methods, 53(2), 245-252. doi:10.1016/s0167-7012(03)00028-9

Dunz, A. R., \& Schliewen, U. K. (2013). Molecular phylogeny and revised classification of the haplotilapiine cichlid fishes formerly referred to as "Tilapia". Molecular Phylogenetics and Evolution, 68(1), 64-80. doi:10.1016/j.ympev.2013.03.015

Ewell, C., Cullis-Suzuki, S., Ediger, M., Hocevar, J., Miller, D., \& Jacquet, J. (2017). Potential ecological and social benefits of a moratorium on transshipment on the high seas. Marine Policy, 81, 293-300. doi:10.1016/j.marpol.2017.04.004

FDA. (2012). Guidance for Industry: The Seafood List | FDA. FDA. Retrieved from https://www.fda.gov/regulatory-information/search-fda-guidance-documents/guidanceindustry-seafood-list

FDA. (2017). Labeling Requirements - Misbranding | FDA. General Device Labeling Requirements: FDA. Retrieved from https://www.fda.gov/medical-devices/generaldevice-labeling-requirements/labeling-requirements-misbranding

FDA. (2018). Seafood Species Substitution and Economic Fraud | FDA. Seafood Guidance Documents \& Regulatory: FDA Retrieved from https:/www.fda.gov/food/seafoodguidance-documents-regulatory-information/seafood-species-substitution-and-economicfraud

FDA. (2020). The Seafood List. from U.S. Food and Drug Administration Retrieved from https://www.accessdata.fda.gov/scripts/fdcc/?set=seafoodlist\&id=Engraulis\%5Fjaponicus 
Fishbase. (2020). Country List - Atheresthes evermanni. Retrieved from https://www.fishbase.de/Country/CountryList.php?ID=518\&GenusName=Atheresthes\&S peciesName $=$ evermanni

Flegenheimer. (2017). Seafood: COOL! (Country of Origin Labeling). Retrieved from http://www.flegenheimer.com/seafood-cool-country-of-origin-labeling/

GAO. (2009). Seafood Fraud: FDA Program Changes and Better Collaboration among Key Federal Agencies Could Improve Detection and Prevention. United States Government Accountability Office:. Retrieved from https://www.gao.gov//assets/290/287425.pdf

Goltz, J. K. (1995). The Sea of Okhotsk Peanut Hole: How the United Nations Draft Agreement on Straddling Stocks Might Preserve The Pollack Fishery (Vol. 4): PAC/ Rim L. \& Pol'y $\mathrm{J}$.

Gucker, E., \& Johnson, M. (1986). Recommended Salmon Quality Guidelines for Fishing, Tendering \& Processing Operations. Alaska Seafood

Handy, S. M., Deeds, J. R., Ivanova, N. V., Hebert, P. D., Hanner, R. H., Weight, L. A., \& Yancy, H. F. (2011). A Single-Laboratory Validated Methods for the Generation of DNA Barcodes for the Identification of Fish for Regulatory Compliance. Journal of AOAC International, 94(1).

Hanner, R., Becker, S., Ivanova, N. V., \& Steinke, D. (2011). FISH-BOL and seafood identification: geographically dispersed case studies reveal systemic market substitution across Canada. Mitochondrial DNA, 22 Suppl 1, 106-122. doi:10.3109/19401736.2011.588217

Hebert, P. D., Cywinska, A., Ball, S. L., \& deWaard, J. R. (2003). Biological identifications through DNA barcodes. Proc Biol Sci, 270(1512), 313-321. doi:10.1098/rspb.2002.2218 
Kerry, J. (2012). Advances in Meat, Poultry and Seafood Packaging. Cambridge: Woodhead Publishing.

Khaksar, R., Carlson, T., Schaffner, D. W., Ghorashi, M., Best, D., Jandhyala, S., . . Amini, S. (2015). Unmasking seafood mislabeling in U.S. markets: DNA barcoding as a unique technology for food authentication and quality control. Food Control, 56, 71-76. doi:10.1016/j.foodcont.2015.03.007

Lagasse, L. P., Love, D. C., \& Smith, K. C. (2014). Country-of-origin labeling prior to and at the point of purchase: an exploration of the information environment in Baltimore City grocery stores. Ecol Food Nutr, 53(1), 58-80. doi:10.1080/03670244.2014.854605

Liou, P., Banda, A., Isaacs, R. B., \& Hellberg, R. S. (2020). Labeling compliance and species authentication of fish fillets sold at grocery stores in Southern California. Food Control, 112. doi:10.1016/j.foodcont.2020.107137

Lowther, A., Liddel, M., Yencho, M., \& NMFS. (2020). Fisheries of the United States 2018. Current Fishery Statistics(2018).

Miller, D. D., \& Mariani, S. (2010). Smoke, mirrors, and mislabeled cod: poor transparency in the European seafood industry. Frontiers in Ecology and the Environment, 8(10), $517-$ 521. doi:10.1890/090212

Mitchell, J. K., \& Hellberg, R. S. (2016). Use of the Mitochondrial Control Region as a Potential DNA Mini-Barcoding Target for the Identification of Canned Tuna Species. Food Analytical Methods, 9(10), 2711-2720. doi:10.1007/s12161-016-0460-3

Moody, M. W. (2003). Encyclopedia of Food Sciences and Nutrition (Vol. 2453-2457): Elsevier Ltd. 
Moore. (2019). Rafael settles spill fine; feds auction two boats: Codfather serving prison sentence(6), 12. Retrieved from http://libproxy.chapman.edu/login?url=https://search.ebscohost.com/login.aspx?direct=tr ue\&AuthType=ip,uid\&db=edsggo\&AN=edsgcl.601028327\&site=eds-live

Moore, Handy, S. M., Haney, C. J., Pires, G. S., Perry, L. L., Deeds, J. R., \& Yancy, H. F. (2012). Updates to the FDA Single Laboratory Validated Method for DNA Barcoding for the Species Identification of Fish. Retrieved from https://www.researchgate.net/publication/271769495_Updates_to_the_FDA_single_labor atory_validated_method_for_DNA_barcoding_for_the_species_identification_of_fish

Naaum, A. M., \& Hanner, R. H. (2016). An Introduction to DNA-Based Tools for seafood Idenitifiaction Seafood Authenticity and Traceability.

NFI. (2016). Industry Guidance of Best Practices for Addressing Seafood Fraud. Retrieved from https://www.aboutseafood.com/wp-content/uploads/2018/05/BSB-Best-PracticeGuidance-November-2017.pdf

NIST. (2011). Maximum Allowable Variation for Packages

NOAA. (2014). Illegal, Unregulated, and Unreported Fishing and Seafood Fraud. Retrieved from https:/www.iuufishing.noaa.gov/

NOC. (2014). Presidential Task Force on Combating IUU Fishing and Seafood Fraud- Action Plan for Implementing the Task Force Recommendations. Retrieved from https://www.iuufishing.noaa.gov/Portals/33/noaa_taskforce_report_final.pdf\#page $=6$

Pollack, S. J., Kawalek, M. D., Williams-Hill, D. M., \& Hellberg, R. S. (2018). Evaluation of DNA barcoding methodologies for the identification of fish species in cooked products. Food Control, 84, 297-304. doi:10.1016/j.foodcont.2017.08.013 
Pramod, G., Nakamura, K., Pitcher, T. J., \& Delagran, L. (2014). Estimates of illegal and unreported fish in seafood imports to the USA. Marine Policy, 48, 102-113. doi:10.1016/j.marpol.2014.03.019

Rouse, M., \& Daniel, D. (2016). Traceablity Retrieved from https://searcherp.techtarget.com/definition/traceability

Santos, J., Roheim, C., \& Durham, K. (2010). Final Report: Improving the Economic Integrity of the U.S. Seafood Industry: Analysis of the Costs of Short Weighting. National Fisheries Institute. .

Seafish. (2008). Glazing: Research and Development Fact Sheet (Vol. FS2-05.08): Seafish, the authority on seafood

Seafish. (2014). Species Guide- Pollack. Seafish the authority on seafood. Species Guide, 4.

Sefcik, D. (2011). Seafood Fraud - Where Are We Now. Weights and Measures Connection, 2(7). Retrieved from https://www.nist.gov/publications/seafood-fraud-where-are-we-now

Shokralla, S., Hellberg, R. S., Handy, S. M., King, I., \& Hajibabaei, M. (2015). A DNA MiniBarcoding System for Authentication of Processed Fish Products. Sci Rep, 5, 15894. doi:10.1038/srep15894

Silva, J. L., Ammeman, G. R., \& Dean, S. . (2001). Processing Channel Catfish. Southern Regional Aquaculture Center. Retrieved from http://agrilife.org/fisheries2/files/2013/09/SRAC-Publication-No.-183-ProcessingChannel-Catfish.pdf

Soares, N. (2016). Updating Use of Glazing in the Frozen Seafood Industry. Retrieved from https://www.foodqualityandsafety.com/article/updating-use-of-glazing-in-the-frozenseafood-industry/ 
Soares, N., Oliveira, M., \& Vicente, A. (2015). Effects of glazing and chitosan-based coating application on frozen salmon preservation during six-month storage in industrial freezing chambers. LWT - Food Science and Technology, 61(2), 524-531. doi:10.1016/j.lwt.2014.12.009

Sterling, B., Gooch, M., Dent, B., Marenick, N., Miller, A., \& Sylvia, G. (2015). Assessing the Value and Role of Seafood Traceability from an Entire Value-Chain Perspective. Comprehensive Reviews in Food Science and Food Safety, 14(3), 205-268. doi:10.1111/1541-4337.12130

Tinch, R., Dickie, I., \& Lanz, B. (2008). Costs of Illegal, Unreported and Unregulated (IUU) Fishing in EU Fisheries Economics for the Environment Consultancy Ltd

UCD. (2010). 25\% of fish products labeled and sold as cod and haddock are from different species, research shows. Retrieved from https://www.ucd.ie/news/2010/04APR10/230410_cod.html

Upton, H. F. (2015). Seafood Fraud. Congressional Research Service Retrieved from https://nationalaglawcenter.org/wp-content/uploads/assets/crs/RL34124.pdf

USDA. (2002). Public Law 107-171 -- Farm Security and Rural Investment Act of 2002 | Animal Welfare Information Center| NAL | USDA. Retrieved from https://www.nal.usda.gov/awic/public-law-107-171-farm-security-and-rural-investmentact-2002

USDA. (2020). Country of Origin Labeling (COOL) $\mid$ Agricultural Marketing Service. Retrieved from https://www.ams.usda.gov/rules-regulations/cool 
Vanhaecke, L., Verbeke, W., \& De Brabander, H. F. (2010). Glazing of frozen fish: analytical and economic challenges. Anal Chim Acta, 672(1-2), 40-44. doi:10.1016/j.aca.2010.03.045

Wang, D., \& Hsieh, Y.-H. P. (2016). The use of imported pangasius fish in local restaurants. Food Control, 65, 136-142. doi:10.1016/j.foodcont.2016.01.016

Warner, K., Timme W., Lowell B., \& Hirshfield, M. (2013). Oceana Study Reveals Seafood Fraud Nationwide. Retrieved from https://oceana.org/reports/oceana-study-revealsseafood-fraud-nationwide

Willette, D. A., Simmonds, S. E., Cheng, S. H., Esteves, S., Kane, T. L., Nuetzel, H., .. . Barber, P. H. (2017). Using DNA barcoding to track seafood mislabeling in Los Angeles restaurants. Conserv Biol, 31(5), 1076-1085. doi:10.1111/cobi.12888

Wong, E. H. K., \& Hanner, R. H. (2008). DNA barcoding detects market substitution in North American seafood. Food Research International, 41(8), 828-837. doi:10.1016/j.foodres.2008.07.005

Yohannes, K., Dalton, C. B., Halliday, L., Unicomb, L. E., \& Kirk, M. (2002). An outbreak of gastrointestinal illness associated with the consumption of escolar fish(3), 441. Retrieved from http://libproxy.chapman.edu/login?url=https://search.ebscohost.com/login.aspx?direct=tr ue \&AuthType=ip,uid\&db=edsbl\&AN=RN121193565\&site=eds-live

Zimmerhackel, J. S., Rogers, A. A., Meekan, M. G., Ali, K., Pannell, D. J., \& Kragt, M. E. (2018). How shark conservation in the Maldives affects demand for dive tourism. Tourism Management, 69, 263-271. doi:10.1016/j.tourman.2018.06.009 